Prepared in cooperation with the North Dakota State Water Commission

\title{
Stochastic Model for Simülating Souris River Basin Regulated Streamflow Upstream from Minot, North Dakota
}

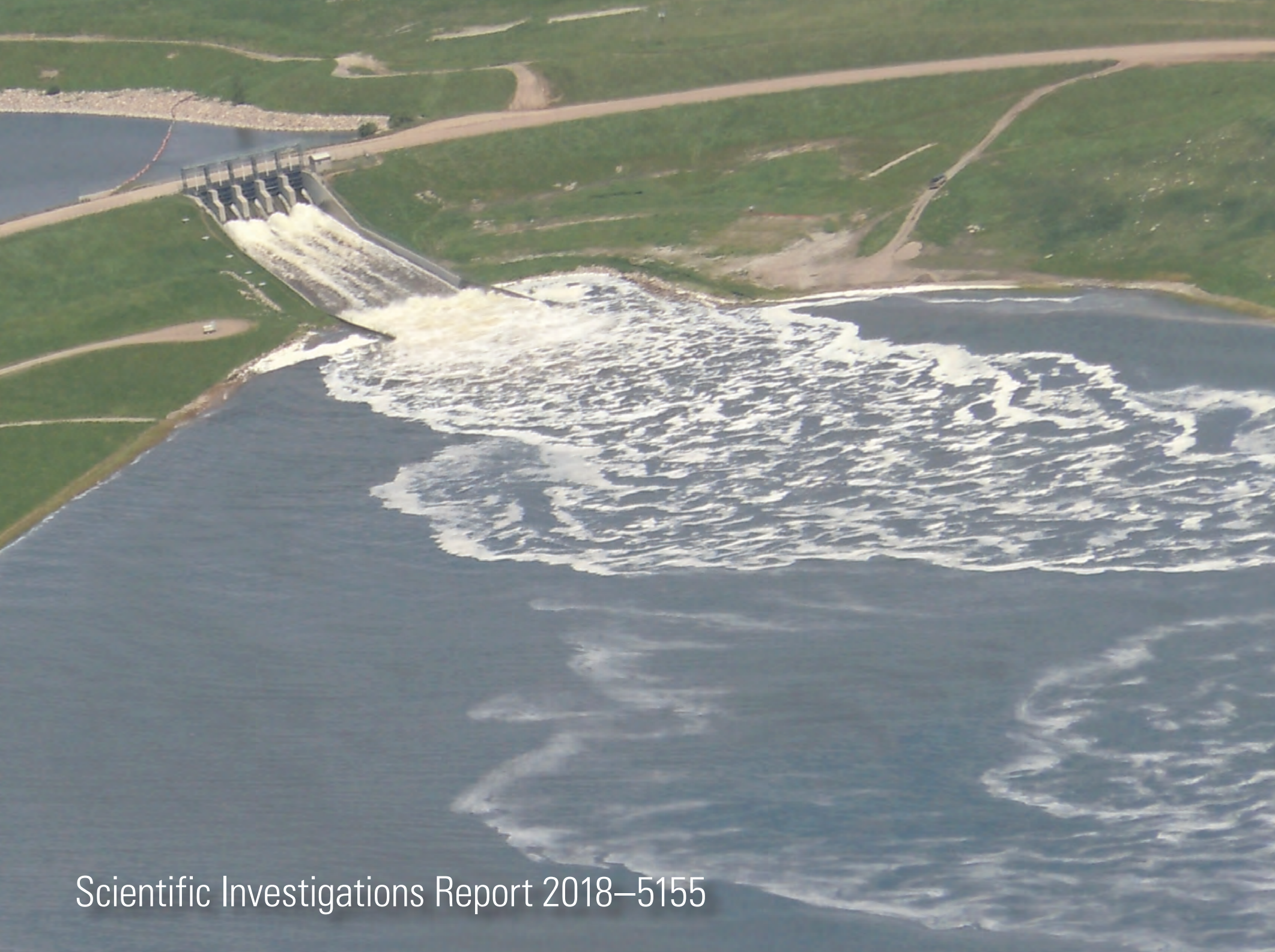

Scientific Investigations Report 2018-5155

U.S. Department of the Interior U.S. Geological Survey 
Cover: Rafferty Dam located in Saskatchewan, Canada. Back cover: Lake Darling located near Minot, North Dakota (top photograph); Alameda Dam (renamed Grant Devine Dam in 2017) located in Saskatchewan, Canada (lower photograph). Photographs by Joel Galloway, U.S. Geological Survey, June 11, 2011. 


\section{Stochastic Model for Simulating Souris River Basin Regulated Streamflow Upstream from Minot, North Dakota}

By Kelsey A. Kolars, Aldo V. Vecchia, and Joel M. Galloway

Prepared in cooperation with the North Dakota State Water Commission

Scientific Investigations Report 2018-5155 


\title{
U.S. Department of the Interior \\ DAVID BERNHARDT, Acting Secretary
}

\author{
U.S. Geological Survey \\ James F. Reilly II, Director
}

U.S. Geological Survey, Reston, Virginia: 2019

For more information on the USGS - the Federal source for science about the Earth, its natural and living resources, natural hazards, and the environment-visit https://www.usgs.gov or call 1-888-ASK-USGS.

For an overview of USGS information products, including maps, imagery, and publications,

visit https://store.usgs.gov.

Any use of trade, firm, or product names is for descriptive purposes only and does not imply endorsement by the U.S. Government.

Although this information product, for the most part, is in the public domain, it also may contain copyrighted materials as noted in the text. Permission to reproduce copyrighted items must be secured from the copyright owner.

Suggested citation:

Kolars, K.A., Vecchia, A.V., and Galloway, J.M., 2019, Stochastic model for simulating Souris River Basin regulated streamflow upstream from Minot, North Dakota: U.S. Geological Survey Scientific Investigations Report 2018-5155, 24 p., https://doi.org/10.3133/sir20185155.

ISS328-0328 (online) 


\section{Acknowledgments}

The authors thank Beth Faber of the U.S. Army Corps of Engineers for her helpful technical review. We also thank Chanel Mueller and Mitch Weier of the U.S. Corps of Engineers and Tim Fay, Laura Ackerman, and Chris Korkowski of the North Dakota State Water Commission for providing valuable technical guidance. 



\section{Contents}

Acknowledgments ……...................................................................................................................

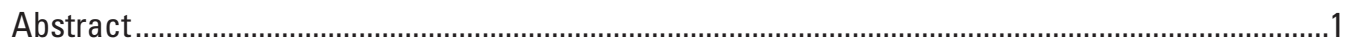

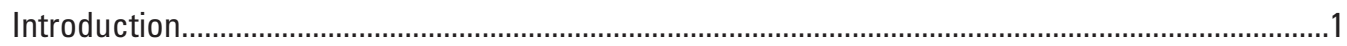

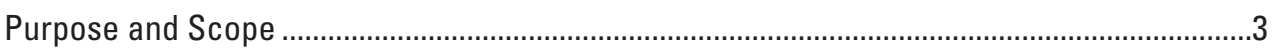

Review of Stochastic Natural (Unregulated) Streamflow Model ..............................................

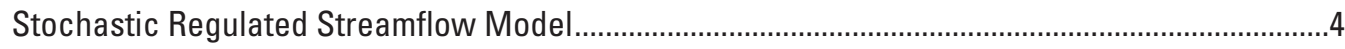

Methods for Developing the Regulated Reservoir Storage/Streamflow Routing Model .........4

Reservoir Water-Balance Approach ................................................................................

Reservoir Operation ....................................................................................................

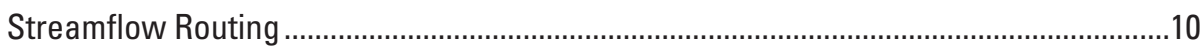

Regulated Reservoir Storage/Streamflow Routing Model Results .................................12

Methods for Developing the Stochastic Regulated Streamflow Model..................................12

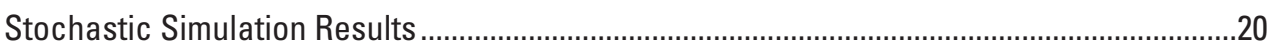

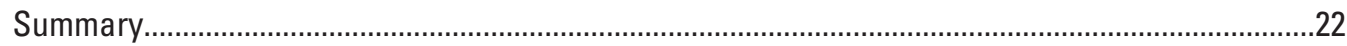

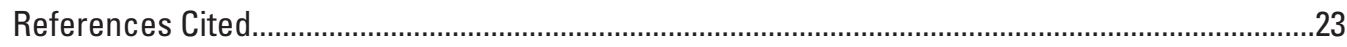

\section{Figures}

1. Map showing Souris River Basin showing locations of major reservoirs and streamgages used for developing the stochastic model for simulating regulated streamflow in the Souris River upstream from Minot, North Dakota..................................2

2. Schematic of reservoir water balance accounting for reservoir inflows, evaporation, seepage, and reservoir releases.

3. Graph showing comparison of Rafferty Reservoir gains and losses in 2001, a flood

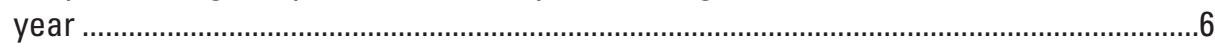

4. Graph showing comparison of Rafferty Reservoir gains and losses in 2004, a nonflood year.

5. Graph showing comparison of measured and simulated Rafferty Reservoir volumes through use of a water-balance approach with the inclusion of a seepage rate .............7

6. Schematic of reservoir operation given four scenarios for the current reservoir level in relation to the target drawdown level and ideal reservoir level...........................9

7. Schematic of regulated reservoir storage/streamflow routing model and the order in which streamflows are determined and routed down to Minot, North Dakota...........11

8. Graph showing comparison of measured and simulated reservoir volumes and releases for Rafferty Reservoir from 1997 through 2011 ................................................13

9. Graph showing comparison of measured and simulated reservoir volumes and releases for Alameda Reservoir from 1999 through 2011 .............................................13

10. Graph showing comparison of measured and simulated reservoir volumes and releases for Boundary Reservoir from 1992 through 2011.

11. Graph showing comparison of measured and simulated reservoir volumes and releases for Lake Darling from 1992 through 2011 
12. Graph showing 10-day mean measured and simulated streamflow at Souris River above Minot, North Dakota, 1992-2011.

13. Graph showing annual measured and simulated streamflow volumes at Souris River above Minot, North Dakota, 1993-2011

14. Graphs showing simulated 10-day mean streamflow for 100-year simulation period for the Souris River above Minot, North Dakota

15. Graphs showing simulated 10 -day mean streamflow for 100 -year simulation period for the Souris River above Minot, North Dakota

16. Graph showing difference between recorded annual peak streamflow and recorded annual maximum 10-day mean streamflow, as a percent of annual maximum 10-day mean streamflow, for the streamgages Souris River above Minot, North Dakota, and Souris River near Sherwood, North Dakota

17. Graph showing estimated flood frequency curves for annual maximum 10-day mean streamflow for the Souris River above Minot, North Dakota, for natural and regulated conditions and three climatic conditions

18. Graph showing estimated flood frequency curves for annual instantaneous peak streamflow for the Souris River above Minot, North Dakota, for regulated conditions and three future climatic conditions.

\section{Tables}

1. Monthly evaporation rates for April-October for Rafferty, Alameda, and Boundary Reservoirs and Lake Darling.....

2. Seepage rates for Rafferty, Alameda, and Boundary Reservoirs and Lake Darling for a 10-day time step.

3. Reservoir and channel capacities, as defined in Annex A, used within the stochastic regulated streamflow model.

4. Lags applied to 10-day streamflow routing model

5. Correlation coefficients and root mean-square error between measured and simulated 10-day mean reservoir volumes for Rafferty, Alameda, and Boundary Reservoirs and Lake Darling.....

6. Correlation coefficients and root mean-square error between measured and simulated 10-day mean reservoir releases for Rafferty, Alameda, and Boundary Reservoirs and Lake Darling.....

7. Estimated peak streamflow magnitudes for the Souris River above Minot, North Dakota, for annual exceedance probabilities of 10, 5, 2, 1, 0.5, and 0.2 percent and three climatic conditions 


\section{Conversion Factors}

U.S. customary units to International System of Units

\begin{tabular}{lcl}
\hline \multicolumn{1}{c}{ Multiply } & By & To obtain \\
\hline foot $(\mathrm{ft})$ & Length & meter $(\mathrm{m})$ \\
\hline & 0.3048 & \\
\hline square mile $\left(\mathrm{mi}^{2}\right)$ & Area & square kilometer $\left(\mathrm{km}^{2}\right)$ \\
\hline & 2.590 & \\
\hline acre-foot $($ acre-ft) & Volume & cubic meter $\left(\mathrm{m}^{3}\right)$ \\
acre-foot $($ acre-ft) & 1,233 & cubic hectometer $\left(\mathrm{hm}^{3}\right)$ \\
\hline & 0.001233 & \\
\hline cubic foot per second $\left(\mathrm{ft}^{3} / \mathrm{s}\right)$ & Flow rate & cubic meter per second $\left(\mathrm{m}^{3} / \mathrm{s}\right)$ \\
\hline
\end{tabular}

Temperature in degrees Celsius $\left({ }^{\circ} \mathrm{C}\right)$ may be converted to degrees Fahrenheit $\left({ }^{\circ} \mathrm{F}\right)$ as follows:

$$
{ }^{\circ} \mathrm{F}=\left(1.8 \times{ }^{\circ} \mathrm{C}\right)+32 .
$$

Temperature in degrees Fahrenheit $\left({ }^{\circ} \mathrm{F}\right)$ may be converted to degrees Celsius $\left({ }^{\circ} \mathrm{C}\right)$ as follows:

$$
{ }^{\circ} \mathrm{C}=\left({ }^{\circ} \mathrm{F}-32\right) / 1.8 .
$$

\section{Datum}

Vertical coordinate information for Canadian reservoirs is referenced to the Geodetic Survey of Canada Datum and for the U.S. reservoir it is referenced to the National Geodetic Vertical Datum of 1929 (NGVD 1929). 


\section{Abbreviations}

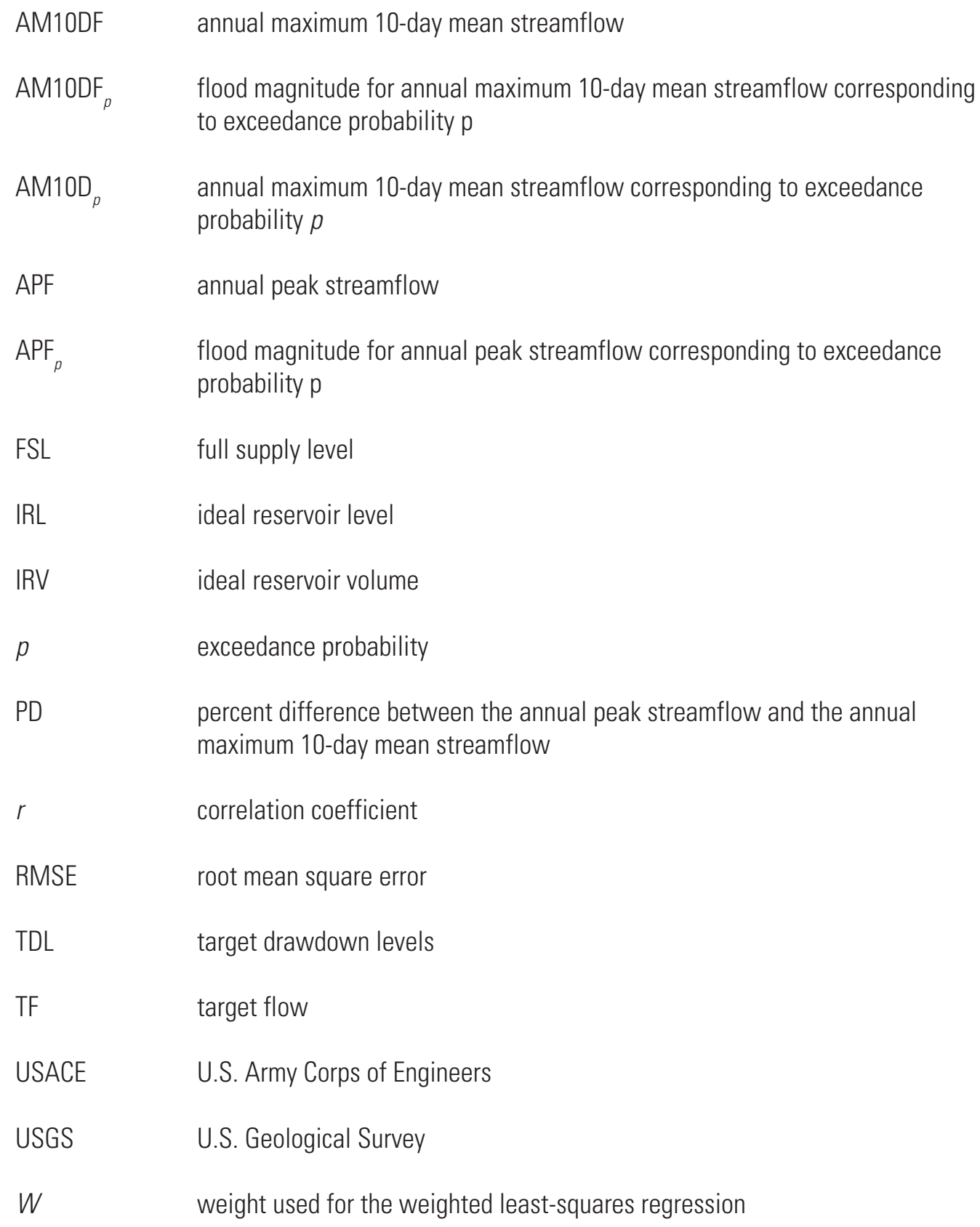




\title{
Stochastic Model for Simulating Souris River Basin Regulated Streamflow Upstream from Minot, North Dakota
}

\author{
By Kelsey A. Kolars, Aldo V. Vecchia, and Joel M. Galloway
}

\section{Abstract}

The Souris River Basin is a 24,000 square-mile basin in the Provinces of Saskatchewan and Manitoba in Canada, and the State of North Dakota in the United States. Above-average snowpack during the winter of 2010-11, along with record-setting rains in May and June of 2011, led to record flooding that caused extensive damage to Minot, North Dakota, and numerous smaller communities in Saskatchewan, Manitoba, and North Dakota. As a result, the International Souris River Board created the Souris River Flood Task Force to evaluate potential reservoir operation changes and flood control measures to manage future floods and droughts. Part of this evaluation involved identifying a need for a stochastic streamflow model to estimate the likelihood of future flooding or drought.

A stochastic natural (unregulated) streamflow simulation model described in a previous report was built upon in this report to include the effects of regulation of four reservoirs (Rafferty, Alameda, and Boundary Reservoirs and Lake Darling) and their operation guidelines. First, a regulated reservoir storage/streamflow routing model was developed and calibrated from when all four reservoirs were in operation until the end of the reconstructed natural streamflow dataset provided by the U.S. Army Corps of Engineers (1992-2011). The regulated reservoir storage/streamflow routing model then was combined with the stochastic natural (unregulated) streamflow model to provide a stochastic regulated streamflow simulation model for the Souris River Basin upstream from Minot, North Dakota.

The stochastic regulated streamflow simulation model was used to estimate regulated flood frequency curves, which are useful for feasibility and design of critical structures such as levees or bridges. Three potential future climatic conditions were considered in this analysis: condition A (wet equilibrium), representing wet (similar to 1970-2017) climatic conditions; condition B (transition), representing transition from wet to dry (similar to 1912-69) climatic conditions; and condition $\mathrm{C}$ (dry equilibrium), representing dry climatic conditions. Comparison of the estimated flood frequency curves for regulated flow among the three climatic conditions indicated large differences in flood magnitudes for the more extreme (1-percent or less) annual exceedance probabilities. The estimated 0.2-percent annual exceedance probability flood magnitude for the Souris River upstream from Minot, N. Dak., was 29,300 cubic feet per second for condition A (wet equilibrium), compared to 14,800 cubic feet per second for condition C (dry equilibrium). For comparison, the recorded peak streamflow for 2011 for the Souris River upstream from Minot, N. Dak., was 26,900 cubic feet per second. Although it is not possible to predict how long the current (1970-2017) wet climatic conditions may persist, flood risk for at least the next 25 years, or until about 2040, may be represented best by climatic condition A.

\section{Introduction}

The Souris River Basin is a 24,000 square-mile basin in the Provinces of Saskatchewan and Manitoba in Canada and the State of North Dakota in the United States (fig. 1). Above-average snowpack during the winter of 2010-11, along with record-setting rains in May and June of 2011, resulted in historically unprecedented flooding in the Souris River Basin (Vining and others, 2013). The 2011 flood caused extensive damage to Minot, N. Dak., and numerous smaller communities in Saskatchewan, Manitoba, and North Dakota. The severe flooding prompted the International Souris River Board to create a Souris River Flood Task Force, which prepared a plan of study for evaluating potential reservoir operation changes and flood control measures to manage future floods and droughts (International Souris River Board, 2013). The task force plan indicated a need for developing stochastic streamflow simulation methods to estimate the likelihood of future floods or droughts that may be extreme on the basis of the available historical record but may not be so extreme in a much longer historical context. In response to this need, the U.S. Geological Survey (USGS), in cooperation with the North Dakota State Water Commission, developed a stochastic model for simulating precipitation, evapotranspiration, and natural (unregulated) streamflow in the Souris River Basin (Kolars and others, 2016). 


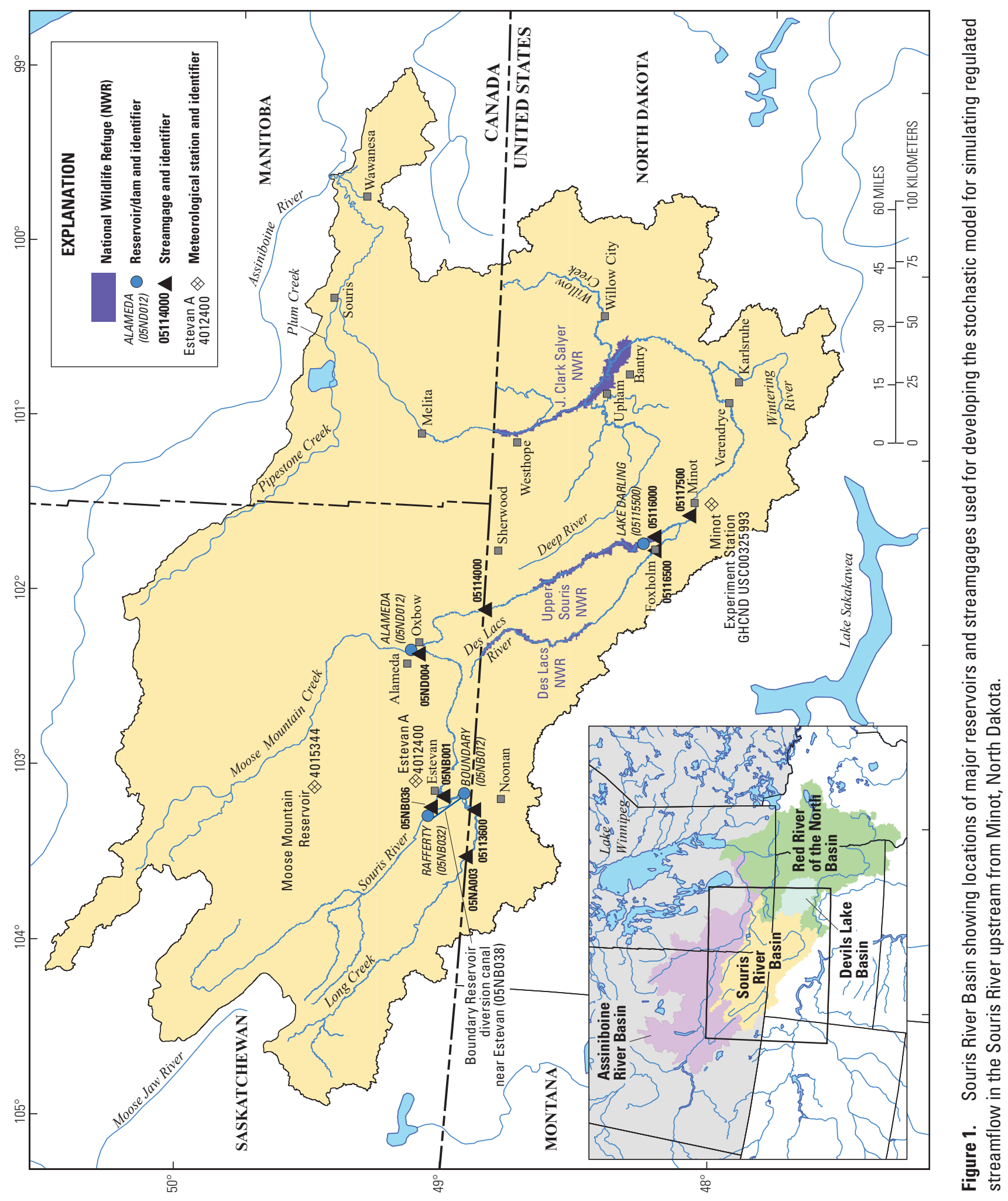


Stochastic modeling takes into account the frequency of past climatic events and simulates a series of future realizations of climatic inputs with the same probability distribution as the historical record but with climatic events happening in a variety of orders within each realization. These future realizations of the climatic inputs represent all potential outcomes including multiyear wet or dry periods that are more extreme than any wet or dry periods in the historical period of record.

The task force also identified the need to develop a stochastic model incorporating regulated streamflow for the Souris River Basin upstream from Minot, N. Dak. The flow upstream from Minot, N. Dak., is affected by regulation from Rafferty, Alameda, and Boundary Reservoirs in Saskatchewan and Lake Darling in North Dakota (fig. 1). The reservoirs currently (2017) are operated according to an international agreement between Canada and the United States (International Joint Commission, 1989). To address this need, the USGS, in cooperation with the North Dakota State Water Commission, built upon the stochastic natural (unregulated) streamflow simulation model described in Kolars and others (2016) by incorporating a reservoir storage/streamflow routing model to simulate regulated streamflow for the Souris River Basin upstream from Minot, N. Dak. The stochastic model for simulating regulated streamflow presented in this report uses the simulated climatic inputs from the unregulated model and accounts for the accumulation (or depletion) of available water storage in the soil profile and the resulting runoff to nearby streams given intermittent periods of wet and dry. Incorporating regulation into a stochastic model, specifically regulation through a series of reservoirs, allows for the accumulation or depletion of water stored within the reservoirs. Rules governing the storage and release of water from the reservoirs affect streamflow and corresponding regulated flood frequency relations. Standard statistical methods for flood frequency analysis are based on an observed streamflow record and do not necessarily take into account regulation or the accumulation of water, either in the soil profile or through reservoirs, and their effect on streamflow. The stochastic model for simulating regulated streamflow in the Souris River Basin described in this report accounts for cumulative effects; however, the model was developed using a relatively short historical record of observations available to validate model predictions and assumptions. Model assumptions used for the regulated streamflow routing model, described in this report, as well as model assumptions used for the natural streamflow simulation model, described in Kolars and others (2016), need to be carefully considered.

The statistical software R (version 3.4.0; R Core Development Team, 2015) was used to develop the stochastic natural streamflow simulation model described in Kolars and others (2016). The natural streamflow model, which simulates streamflow for an approximately 10-day (3 values per month) time step, was modified as described in this report to incorporate reservoir operation guidelines described in Annex A of the International Joint Commission Agreement (International Joint Commission, 1989; hereafter referred to as "Annex A").
The natural (unregulated) streamflow values generated from the first report were fed as inputs to the stochastic regulated streamflow model to generate regulated 10-day mean streamflow values. The generated 10-day mean streamflow values were used to compute estimated flood frequency distributions for annual maximum 10-day mean streamflow, and a weighted least-squares regression model was developed to estimate flood frequency distributions for annual maximum instantaneous flow given the estimated flood frequency distributions for annual maximum 10-day mean streamflow.

Overall, the stochastic model for simulating regulated streamflow in the Souris River Basin can be used to estimate regulated flood frequency curves and provide useful information for feasibility and design of critical structures such as levees or bridges. The model also can be used to evaluate the effects of proposed changes to the international agreement between Canada and the United States to optimize future reservoir operation for the joint objectives of hydropower generation, water delivery, and flood protection.

\section{Purpose and Scope}

The purpose of this report is to describe the stochastic model for simulating regulated streamflow in the Souris River Basin upstream from Minot, N. Dak., and present results of model simulations of future regulated streamflow for the Souris River upstream from Minot, N. Dak., and the flood frequency estimates to support levee feasibility and design studies being completed by the U.S. Army Corps of Engineers (USACE), the City of Minot, and the North Dakota State Water Commission. The stochastic regulated streamflow model was developed by first developing a regulated reservoir storage/streamflow routing model, and then combining that with the stochastic natural streamflow model described in Kolars and others (2016). The simulated regulated streamflow data from the stochastic model were used to evaluate future flood risk. Flood risk is evaluated assuming current (19922017) reservoir infrastructure and operation is maintained in future years; however, the model can be modified easily for future use to evaluate the effects of proposed changes to the current regulation.

\section{Review of Stochastic Natural (Unregulated) Streamflow Model}

The stochastic model for simulating regulated streamflow described in this report builds upon the stochastic model for simulating natural (unregulated) streamflow described in a previous report (Kolars and others, 2016). Therefore, it is useful to review some key concepts from the previous report before describing the methods and results for the stochastic regulated streamflow model.

The stochastic natural streamflow model (Kolars and others, 2016) consisted of three components: (1) a stochastic climate model for simulating monthly time series of spatially 
distributed precipitation, temperature, and potential evapotranspiration for the Souris River Basin; (2) a water-balance model for estimating monthly runoff (in millimeters per square kilometer) for specified subbasins based on monthly precipitation, snow accumulation and melt, soil-moisture storage, and evapotranspiration; and (3) a temporal disaggregation and streamflow-routing model to simulate approximate 10-day ( 3 values per month) streamflow values for specified streamgage locations. The streamflow values consist of mean streamflow (in cubic feet per second) for the beginning (days 1-10), middle (days 11-20), and end (days 21 through the end of the month) of each month, and are hereafter referred to as "10-day mean streamflow."

The stochastic climate model was developed using recorded monthly precipitation, temperature, and potential evapotranspiration data for 1912-2011 from Canadian and United States meteorological stations in and surrounding the Souris River Basin (Government of Canada, 2014; Menne and others, 2014; Kolars and others, 2016), along with tree-ring chronologies dating back to the early 1700 s (National Oceanic and Atmospheric Administration, National Climatic Data Center, 2014; Ryberg and others, 2016, Kolars and others, 2016). A key conclusion of the climate analysis was that longterm (multidecadal to century-scale) climatic variability in the Souris River Basin is consistent with alternating wet and dry climate states of highly variable and unpredictable durations. One such transition from a dry to wet state likely occurred in the Souris River Basin in about 1970, as evidenced by a highly significant step-like increase in March-October precipitation around that time (Kolars and others, 2016). Thus, for the Souris River Basin, the period from 1970 to present (2017) is characterized by generally wetter conditions (and higher flood risk) compared to prior decades dating back to at least the early 20 th century. The alternating wet and dry climate states are thought to be a manifestation of natural, long-term climatic persistence and are not thought to be associated with climate change or global warming. The implications of this long-term climatic persistence for evaluating future flood risk for the Souris River Basin are described later in this report in the "Methods for Developing the Stochastic Regulated Streamflow Model" section.

The water-balance model for estimating monthly runoff and the temporal disaggregation/streamflow routing model for estimating natural 10-day mean streamflow assumed no reservoir regulation. The models were calibrated and verified using reconstructed natural streamflow data for 1946-2011 provided by the U.S. Army Corps of Engineers (2013), as described in Kolars and others (2016). The water-balance model and the temporal disaggregation part of the disaggregation/streamflow routing model described in that report are identical to the methods used for this report describing the stochastic regulated streamflow model. The only modifications required for developing the stochastic regulated streamflow simulation model were with respect to the streamflow routing part of the model. These modifications are described in the section
"Methods for Developing the Regulated Reservoir Storage/ Streamflow Routing Model."

\section{Stochastic Regulated Streamflow Model}

The stochastic regulated streamflow model was developed by first developing a regulated reservoir storage/streamflow routing model, which is described in the following section "Methods for Developing the Regulated Reservoir Storage/Streamflow Routing Model," and then combining that with the stochastic natural streamflow model described in Kolars and others (2016). The combining of the regulated reservoir storage/streamflow routing model and the previous stochastic natural streamflow model is described later in the report in the section "Methods for Developing the Stochastic Regulated Streamflow Model." The simulated regulated streamflow data from the stochastic model were used to evaluate future flood risk as described later in the report in the section "Stochastic Simulation Results." Flood risk is evaluated assuming current (1992-2017) reservoir infrastructure and operation is maintained in future years; however, the model can be modified easily for future use to evaluate the effects of potential changes to the current regulation.

\section{Methods for Developing the Regulated Reservoir Storage/Streamflow Routing Model}

The regulated reservoir storage/streamflow routing model builds upon the stochastic natural streamflow model developed previously in Kolars and others (2016) by including the effects of four reservoirs (Rafferty, Alameda, and Boundary Reservoirs and Lake Darling) and their operation according to guidelines described in Annex A (International Joint Commission, 1989). The regulated reservoir storage/streamflow routing model was calibrated for the period between 1992 and 2011, the period between construction of the last reservoir (1992) and the end of the natural streamflow dataset (2011) provided by the U.S. Army Corps of Engineers (2013). Development of the regulated reservoir storage/streamflow routing model consisted of three main parts. First, the regulated reservoir storage/streamflow routing model required an understanding of the reservoir water balance to determine seepage rates and effectively capture reservoir storage changes. Second, operation of the reservoirs was simulated considering current and forecasted inflows, reservoir storage changes, and guidelines provided in Annex A. Third, reservoir releases and intervening runoff from downstream subbasins were routed down to Minot, N. Dak. (Souris River above Minot, N. Dak., USGS streamgage 05117500; fig. 1; U.S. Geological Survey, 2017), using the regulated reservoir storage/streamflow routing model. 


\section{Reservoir Water-Balance Approach}

A reservoir water-balance approach was used to estimate reservoir storage changes in response to reservoir inflow and outflow (releases from the reservoir plus evaporation), along with estimated losses due to seepage (fig. 2). If all inflows and outflows (including evaporation) from a reservoir are known, and the reservoir still experiences a loss of storage during the 10-day period, then that loss is assumed to be attributed to seepage. The USACE estimated daily natural inflows to the Canadian reservoirs as a residual through the use of a waterbalance approach by taking known reservoir outflows and storage relations and backcalculating reservoir inflows (U.S. Army Corps of Engineers, 2013). More details on how inflows were estimated are provided in U.S. Army Corps of Engineers (2013). For the current study, a water-balance approach similar to the one used by the U.S. Army Corps of Engineers (2013) was used to backcalculate seepage rates with the same evaporation, reservoir releases, and storage relations being used in the USACE water balance and the reservoir water balance in this report, except the USACE considers a daily time step and the reservoir water balance in this report considers a 10-day time step. Additionally, the U.S. Army Corps of Engineers (2013) water balance used reservoir water levels that had been smoothed with an $n$-day mean to compensate for wind wave effects. The reservoir water-balance approach described in this report simply used the mean daily recorded reservoir level at the start of the 10-day time step. Specifically, for Lake Darling, the recorded reservoir levels were sporadic, so reconstructed reservoir levels provided by the U.S. Army Corps of Engineers (2013) were used. A schematic of the reservoir water balance is given in figure 2 .

Evaporation rates for Rafferty and Boundary Reservoirs were measured at Estevan, Saskatchewan (meteorological station Estevan A 4012400; fig. 1), and for Alameda Reservoir, they were measured at Moose Mountain Reservoir

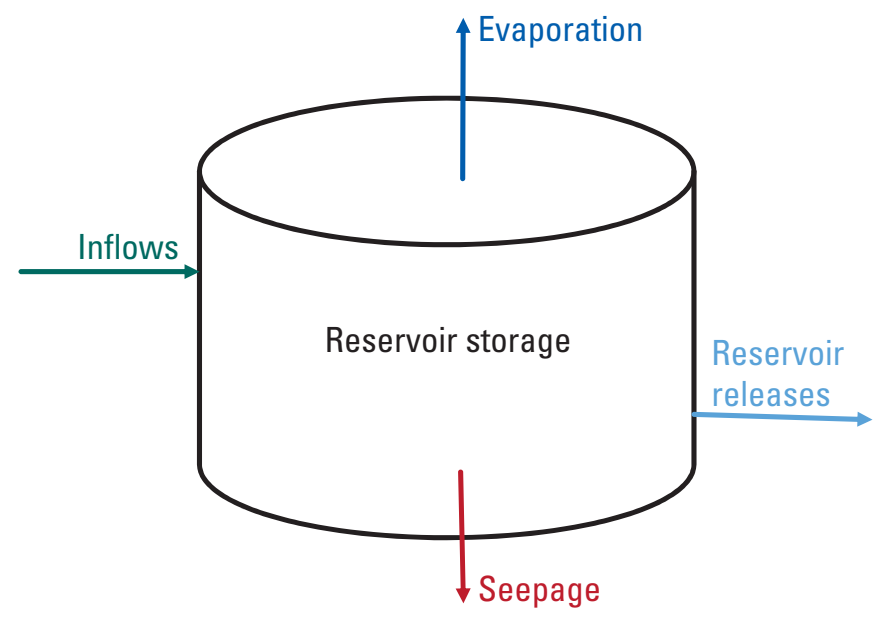

Figure 2. Reservoir water balance accounting for reservoir inflows, evaporation, seepage, and reservoir releases. meteorological station 4015344 (fig. 1); both were provided by the Saskatchewan Water Security Agency (table 1) (U.S. Army Corps of Engineers, 2013). For Lake Darling, the evaporation rates were provided by the National Oceanic and Atmospheric Administration's (NOAA) National Climatic Data Center and measured at the Minot Experiment Station GHCND: USC00325993 (fig. 1) near Minot, N. Dak. (table 1) (U.S. Army Corps of Engineers, 2013).

The storage relations (elevation capacity and elevation area) for the Canadian reservoirs were provided through Annex A (International Joint Commission, 1989, plates 7A-8B). For Lake Darling, a modified storage relation that was provided by the USACE Lake Darling Water Control Manual and presented in the USACE Regional and Reconstructed Hydrology of the Souris River Report for use with a HEC-ResSIM model (Lake Darling Water Control Manual, 2012; U.S. Army Corps of Engineers, 2013) was used by the USACE. These storage relations helped to determine reservoir volume and corresponding surface area, which was used to determine evaporation volumes, from reservoir elevations. Reservoir elevations/levels were provided through Environment and Climate Change Canada water-level gages for Rafferty Reservoir near Estevan (05NB032), Alameda Reservoir near Alameda (05ND012), and Boundary Reservoir near Estevan (05NB012) (Government of Canada, 2017), and through the USGS water-level gage Lake Darling near Foxholm, N. Dak. (streamgage 05115500; U.S. Geological Survey, 2017) (fig. 1). Reservoir releases were measured by Environment and Climate Change Canada streamgages (Government of Canada, 2017) on the Souris River below Rafferty Reservoir (streamgage 05NB036), Moose Mountain Creek near Oxbow (streamgage 05ND004), Boundary Reservoir diversion canal near Estevan (05NB038), and Long Creek near Estevan below Boundary Reservoir (streamgage 05NB001), and by the USGS streamgage on the Souris River near Foxholm, N. Dak. (streamgage 05116000; U.S. Geological Survey,

Table 1. Monthly evaporation rates for April-0ctober for Rafferty, Alameda, and Boundary Reservoirs and Lake Darling.

\begin{tabular}{lccc}
\hline \multirow{2}{*}{ Month } & \multicolumn{3}{c}{ Evaporation, in inches } \\
\cline { 2 - 4 } & $\begin{array}{c}\text { Rafferty and } \\
\text { Boundary }\end{array}$ & Alameda & Lake Darling \\
\hline April & 2.30 & 2.40 & 2.40 \\
May & 5.64 & 4.39 & 4.68 \\
June & 6.39 & 5.40 & 4.45 \\
July & 7.37 & 6.90 & 5.26 \\
August & 7.18 & 5.53 & 5.11 \\
September & 4.91 & 3.49 & 3.61 \\
October & 2.44 & 1.47 & 2.92 \\
\hline
\end{tabular}


2017) (fig. 1). Inflows to the reservoirs were provided by the U.S. Army Corps of Engineers (2013). Specifically, for Rafferty and Boundary Reservoirs, the inflow volumes accounted for the operation of Boundary canal and diverted all historical gaged streamflow through the canal into Rafferty Reservoir (U.S. Army Corps of Engineers, 2013). As a result, during calibration, the reservoir water balance for Rafferty Reservoir includes additional inflows from Boundary canal (Boundary Reservoir diversion canal near Estevan 05NB038; fig. 1) and the reservoir water balance for Boundary Reservoir includes additional outflows to Boundary canal. Inclusion of Boundary canal was necessary to reproduce historical inflows and outflows from the reservoirs for calibration of seepage rates and validation of the reservoir water balance. Operation guidelines for Boundary canal have been left largely to the discretion of the operator with mention in Annex A that the canal "may be used for flood control provided that storage is available in Rafferty Reservoir in excess of the amount required to meet United States flood control requirements in that year, by the amount of volume to be diverted" (International Joint Commission, p. A-22, 1989). For the purpose of this study, operation of Boundary canal was left out of the stochastic regulated streamflow model but was included during calibration of the model to historical streamflows.

The reservoir water-balance model was calibrated by adjusting the seepage rate. Including a seepage rate in the reservoir water-balance model helped compensate for drift and prevented the model from overpredicting actual reservoir volume. Visual inspection (ensuring simulated and measured reservoir volumes were similar) and a high correlation coefficient (greater than 0.9) for the relation between simulated and measured reservoir volumes were considered when determining the seepage rate. The resulting seepage rates, estimated as a percentage of reservoir volume at the start of a 10-day time step, for each reservoir are listed in table 2 . The estimated seepage represents the total seepage (in depth equivalent) during the 10-day time step. Seepage rates were relatively small compared to reservoir inflow and evaporation volumes (figs. 3 and 4).

Table 2. Seepage rates for Rafferty, Alameda, and Boundary Reservoirs and Lake Darling for a 10-day time step.

\begin{tabular}{lll}
\hline \multicolumn{1}{c}{ Reservoir } & Seepage rate $^{\mathbf{1}}$ & $\begin{array}{l}\text { Correlation } \\
\text { coefficient }\end{array}$ \\
\hline Rafferty & 0.175 & 0.997 \\
Alameda & 0.080 & 0.999 \\
Boundary & 0.225 & 0.926 \\
Lake Darling & 0.080 & 0.988 \\
\hline
\end{tabular}

${ }^{1}$ Seepage rates are presented as a percentage of the reservoir volume at the start of the 10-day time step and represent the total seepage (in depth equivalent) over the 10-day time step.
In addition to the inclusion of seepage, the main difference between the U.S. Army Corps of Engineers (2013) waterbalance approach and the reservoir water balance used in this report relates to the USACE use of a daily time step compared to the 10-day time step used in this report. Hence, the resulting reservoir volumes/levels were expected to be similar to historical values because most components of the water-balance approach for both models were the same (fig. 5).

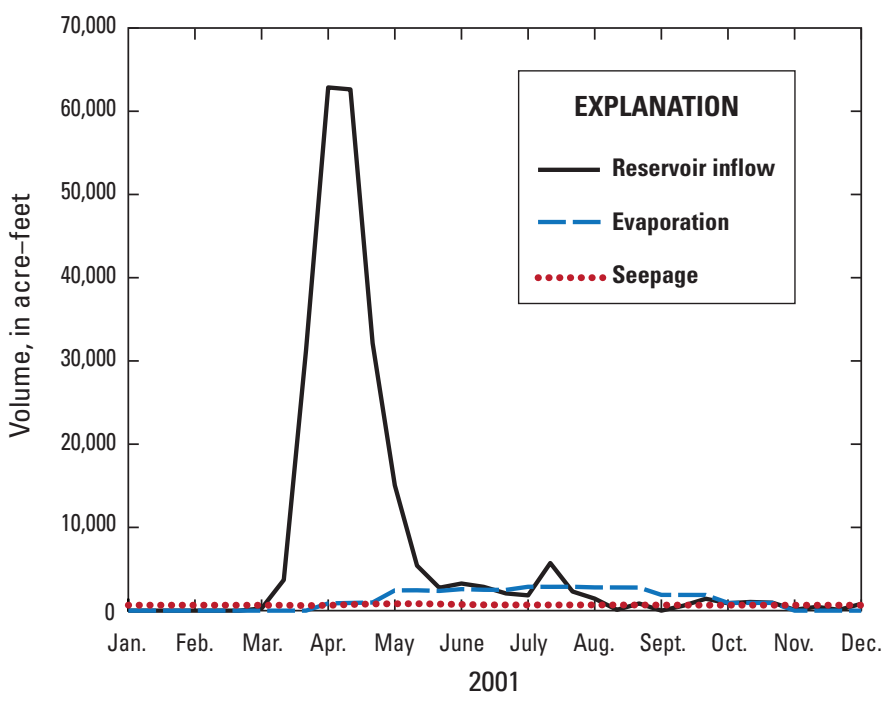

Figure 3. Comparison of Rafferty Reservoir gains (reservoir inflows) and losses (evaporation, seepage) in 2001, a flood year.

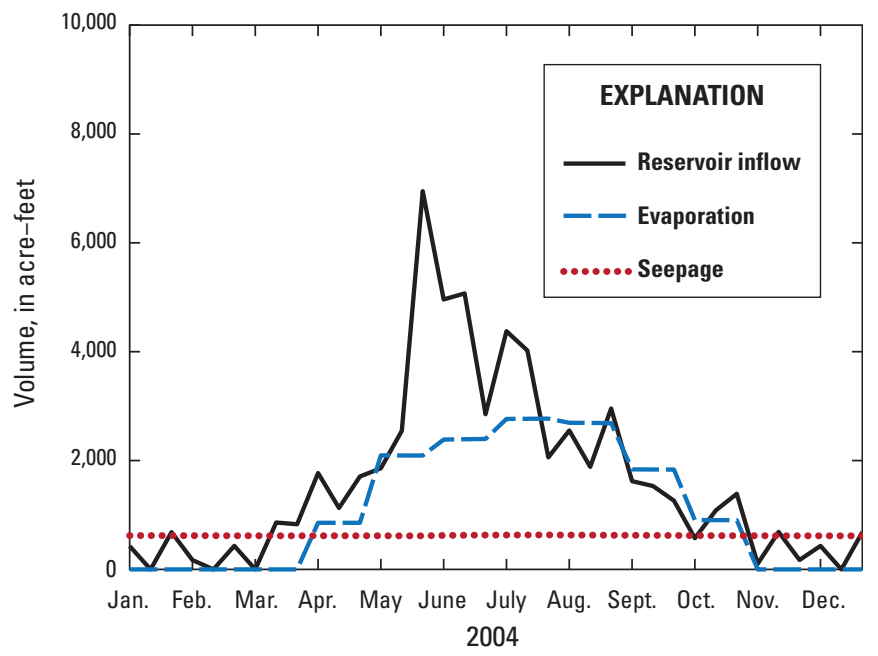

Figure 4. Comparison of Rafferty Reservoir gains (reservoir inflows) and losses (evaporation, seepage) in 2004, a nonflood year. 


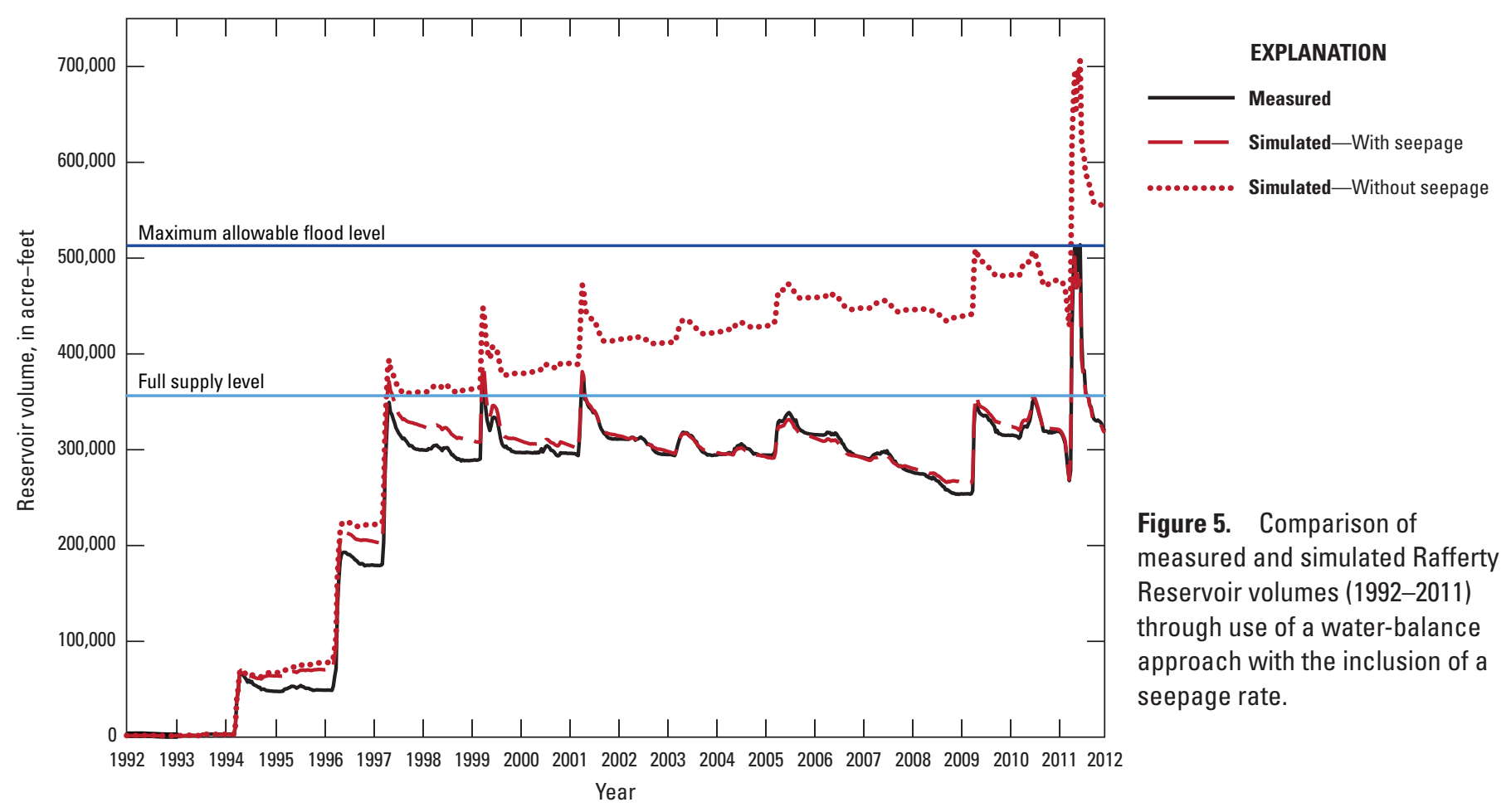

\section{Reservoir Operation}

The reservoir water balance was combined with guidelines from Annex A to determine reservoir operation and releases. Annex A describes the operating plan for Rafferty, Alameda, and Boundary Reservoirs and Lake Darling and forms part of the agreement between the Government of Canada and the Government of the United States for water supply and flood control in the Souris River Basin (International Joint Commission, 1989). The primary objectives of the operating plan are to "(1) provide 1-percent (100-year) flood protection at Minot, N. Dak.; (2) provide flood protection to urban and rural areas downstream from Rafferty Dam, Alameda Dam, and Lake Darling Dam; and (3) ensure, to the extent possible, that the existing benefits from the supply of water in the Souris River Basin and the supply of water to the Souris Basin project are not compromised" (International Joint Commission, 1989). The operating plan was designed to accommodate floods similar to those that had been experienced in 1969, 1974, 1975, 1976, 1979, and 1982 (International Joint Commission, 1989). The operating plan provides detailed guidelines on managing the four reservoirs during flood and nonflood years and modifies these guidelines based on the time of year. Much detail is offered in Annex A, but for purposes of this report, a simplification of Annex A guidelines is used to replicate past operation of the reservoirs. The guidelines in Annex A that have been used in this report and the simplification of some guidelines are further described in the remainder of this section.

The first step in converting the natural streamflow routing model provided in the previous study (Kolars and others, 2016) to a model that included regulation from four reservoirs was determining how much to release from the Canadian reservoirs. Determining the amount to release from each reservoir first depended on the current volume/level of the reservoir and forecasted 30-day inflow volumes. Given the USACE natural streamflow dataset covered the period between 1992 and 2011, the forecasted 30-day inflows already were known and are similar to forecasting 30-day flows with 100-percent accuracy. It is assumed that historical forecasts would have been reasonably close to 30-day inflows derived based on observed data. Annex A provides target drawdown levels (TDLs) for each of the reservoirs depending on forecasted 30- and 90-percent, 90-day inflows (International Joint Commission, 1989, Annex A, plates 1-4). These TDLs increase or decrease depending on the forecasted 30- or 90-percent, 90-day inflow volumes. A large forecasted inflow volume would push the TDL lower to create more storage in the reservoir, whereas a small forecasted inflow volume would push the TDL higher because not nearly as much storage would be needed in the reservoir. The TDLs for Canadian reservoirs are based on forecasted (90-percent chance of exceedance) 90-day inflow volumes to the reservoirs, whereas TDLs for Lake Darling are based on forecasted 30-day inflow volumes (International Joint Commission, 1989). For this report, the TDLs for the Canadian reservoirs were determined using forecasted 30-day inflow volumes, instead of the 90-percent, 90-day inflow volumes, because historical forecasts of the 90 percent, 90-day flow are unavailable, making it difficult to replicate past operation of the reservoirs. Furthermore, actual inflow could be quite different from forecasted values when looking at a large time extent like 90 days. Additionally, during large flood events, much of the flow volume happens within 1 or 2 months (usually during the spring); hence, 30 -day inflows 
were considered to resemble operating decisions based on forecasted flows more closely than 90-day inflows.

In addition to identifying the TDLs for the reservoirs, an ideal reservoir level (IRL) was set such that the reservoir either would release or contain flows to maintain the reservoir level at the IRL. Unlike the TDL, the IRL is static throughout the year and does not change depending on forecasted inflow volumes. When there is no threat of a flood, the IRL is still the objective. If there is a series of dry years, the reservoir volume will fall below the IRL and, without sufficient inflows to keep the volume at the IRL, the reservoir will remain below the IRL and provide more storage for the following years (more storage for potential flood years). For Rafferty and Alameda Reservoirs, this IRL was set to the "normal level prior to spring runoff" defined in Annex A (International Joint Commission, 1989) and provided in table 3. An exception was made for Boundary Reservoir, which does not have a specified "normal level prior to spring runoff." For Boundary Reservoir, the IRL was set 0.33 foot (ft) below the full supply level $(1,840 \mathrm{ft})$ at $1,839.67 \mathrm{ft}$. The TDL (determined by looking at forecasted 30-day inflows) and the IRL were used to determine releases from the Canadian reservoirs. If the current reservoir level $(R L)$ was less than or equal to ( $\leq$; below) the $I R L$ and the $T D L$, then there would be no releases from the reservoirs (fig. $6 A$; eq. 1):

$$
Q_{\text {out }}=0, \text { if } R L \leq I R L \text { and } R L \leq T D L
$$

where

$R L \quad$ is the current reservoir level, in feet;

$I R L \quad$ is the ideal reservoir level, in feet;

$T D L \quad$ is the target drawdown level, in feet; and

$Q_{\text {out }} \quad$ is the reservoir release, in acre-feet, for the current 10-day period.

If the current reservoir level was below the IRL but greater than (>; above) the $T D L$, then the difference between the current reservoir volume and the $T D L$ volume would be released (fig. $6 B$; eq. 2 ):

$$
Q_{\text {out }}=R V-T D V \text {, if } R L \leq I R L \text { and } R L>T D L
$$

where

$R V \quad$ is the current reservoir volume, in acre-feet; and

$T D V$ is the target drawdown volume, in acre-feet. For this last scenario, an exception was made for Boundary

Reservoir where releases were not just the difference between $R V$ and $T D V$, but rather releases were the minimum of either $R V-T D V$ or one-half of the reservoir inflows. This exception was made for Boundary Reservoir to reduce releases because the reservoir also serves as a source of cooling water for the adjacent coal-fired Boundary Dam Power Station.

If the current reservoir level is above the IRL (even when it is below the $T D L$ ) and there is enough storage in the reservoir to hold the anticipated 30-day inflow volume (that is, the $I R L$ is greater than or equal to $[\geq]$ the forecasted

Table 3. Reservoir and channel capacities, as defined in Annex A (International Joint Commission, 1989), used within the stochastic regulated streamflow model.

\begin{tabular}{|c|c|c|c|c|}
\hline \multirow{2}{*}{ Threshold } & \multicolumn{3}{|c|}{ Reservoir } & \multirow{2}{*}{ Lake Darling } \\
\hline & Rafferty & Alameda & Boundary & \\
\hline Ideal reservoir level (IRL), in feet ${ }^{1}$ & ${ }^{2} 1,802.82$ & ${ }^{2} 1,840.55$ & $1,839.67$ & ${ }^{3} 1,597.00$ \\
\hline Normal level before spring runoff, in feet & $1,802.82$ & $1,840.55$ & -- & -- \\
\hline Full supply level, in feet & $1,806.10$ & $1,843.83$ & $1,840.00$ & $1,597.00$ \\
\hline Maximum allowable flood level, in feet & $1,817.59$ & $1,860.24$ & $1,840.00$ & $1,601.00$ \\
\hline Downstream reservoir channel capacity, in $\mathrm{ft}^{3} / \mathrm{s}$ & $\begin{array}{c}500 \\
{ }^{4} 2,295.5\end{array}$ & 1,800 & 900 & $\begin{array}{l}\text { 2,500 (March-May) } \\
500 \text { (other) }\end{array}$ \\
\hline Maximum recorded 10-day release volume, in acre-ft & 69,0651 & 46,580 & 85,729 & $515,701.92$ \\
\hline
\end{tabular}

[--, no data; $\mathrm{ft}^{3} / \mathrm{s}$, cubic foot per second; acre-ft, acre-foot $]$

${ }^{1}$ IRL; static throughout entire year.

${ }^{2}$ For Rafferty and Alameda Reservoirs, the IRL is equivalent to the normal level before spring runoff value provided in Annex A.

${ }^{3}$ For Lake Darling, the IRL is equivalent to the full supply level provided in Annex A.

${ }^{4}$ In the model, the capacity of Rafferty Reservoir's low-flow outlet was used in place of the downstream reservoir channel capacity. 


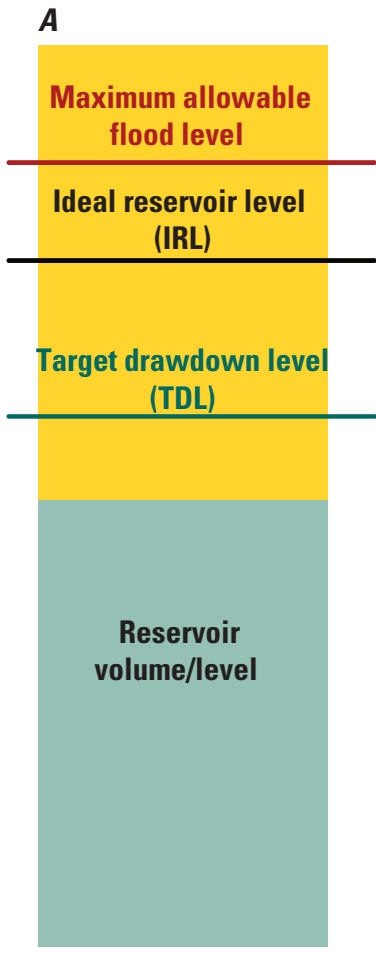

No outflow

\section{$B$}

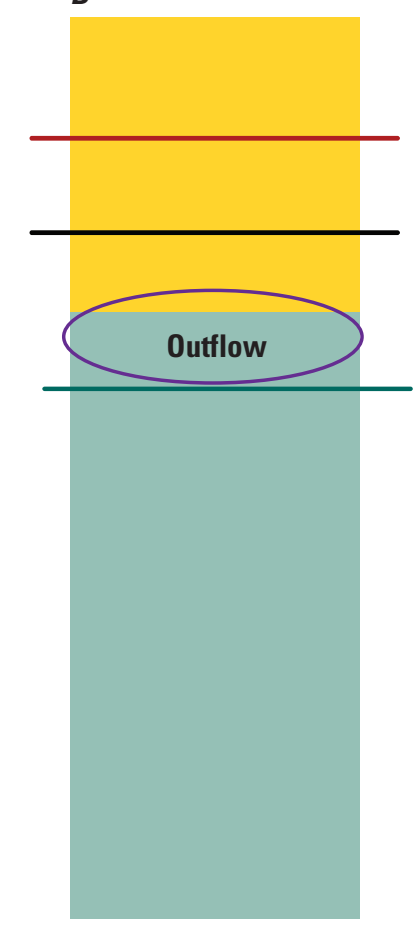

Outflow=reservoir volume-TDL volume $c$

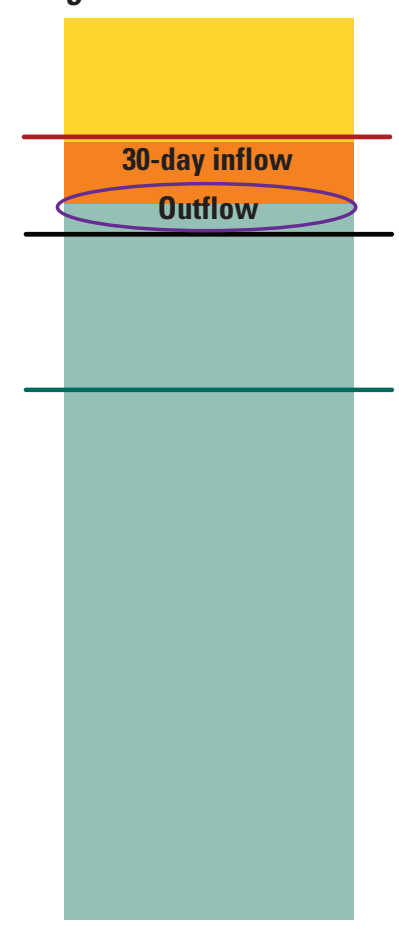

Outflow=minimum (channel capacity, reservoir volume-IRL volume)

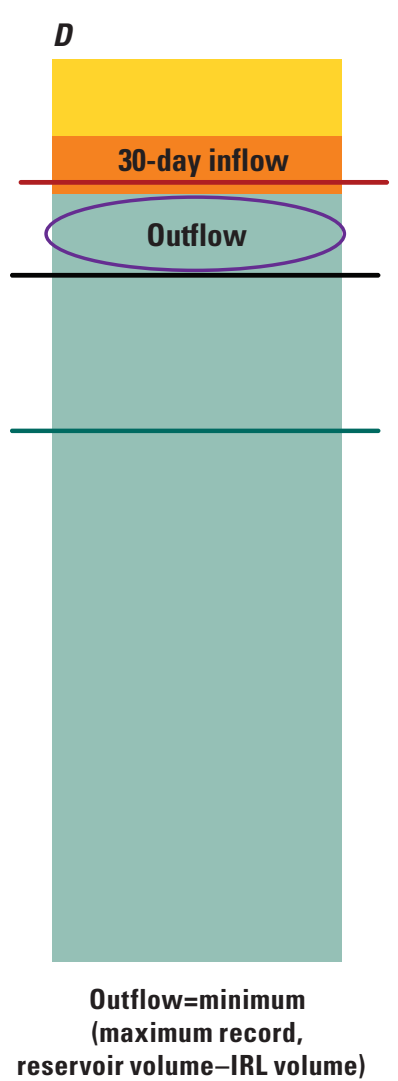

Figure 6. Reservoir operation given four scenarios for the current reservoir level in relation to the target drawdown level (TDL) and ideal reservoir level (IRL). $A$, current reservoir level is less than both the TDL and IRL and there is no outflow from the reservoir; $B$, current reservoir level is greater than the TDL but less than the IRL and outflow is the difference between the current reservoir volume and the TDL volume; $C$, current reservoir level is greater than the IRL, the forecasted 30-day inflow volume does not exceed reservoir storage, and outflow is the minimum of either the channel capacity or the difference between the current reservoir volume and the IRL volume; and $D$, current reservoir level is greater than the IRL, the forecasted 30-day inflow volume does exceed reservoir storage, and outflow is the minimum of either the maximum recorded outflow or the difference between current reservoir volume and the IRL volume. Note that in this figure, the TDL is depicted as lying below the IRL, but the TDL is not a constant value and could rest either above or below the IRL depending on forecasted inflows.

30-day inflow volume), then reservoir releases are calculated to be the minimum of either the channel capacity (just downstream from the reservoir) or the difference between the current reservoir volume and the ideal reservoir volume (IRV). For Lake Darling, the channel capacity changes depending on time of year and is further described later in this section. Additionally, it is important to note that when the current reservoir level is greater than the $I R L$, the target level is no longer the $T D L$ but instead the IRL because a target level of $T D L$, in this scenario, resulted in too much release from the reservoir during the 10-day period. Setting the target level to $I R L$ helped reduce releases and lower the reservoir level at a slower rate. For Rafferty Reservoir, using channel capacity as a threshold resulted in simulated values that were much lower than measured values, and, for this reason, the capacity of the low-flow outlet, 2,295.5 cubic feet per second $\left(\mathrm{ft}^{3} / \mathrm{s}\right.$, table 3$)$ or about 45,530 acre-feet (acre-ft) for the 10-day period, was used instead of channel capacity (fig. $6 C$; eq. 3 ):

$$
\begin{aligned}
& Q_{\text {out }}=\operatorname{minimum}\left(C C_{\max }, R V-I R V\right), \\
& \quad \text { if } R L>I R L \text { and } R S \geq I V_{30 d}
\end{aligned}
$$

where

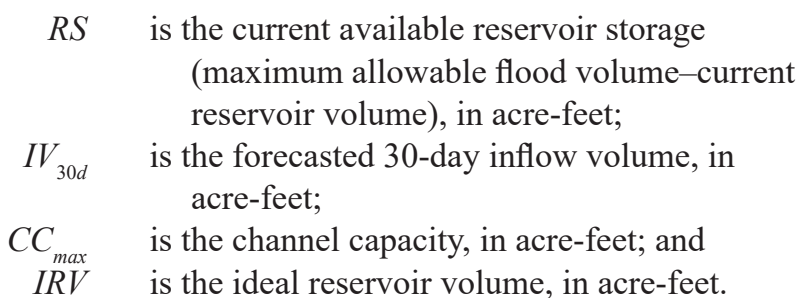
Lastly, when the current reservoir level is above the IRL and there is not enough available storage to hold the anticipated 30-day inflow volume (in other words, the maximum allowable flood level described in table 3 will be exceeded), then the releases are calculated to be the minimum of either the historical maximum measured outflow volume during 10 days or the difference between the current volume and the $I R V$ (fig. $6 D$; eq. 4). For this last scenario, the reservoir releases are no 
longer limited by downstream channel capacities and instead are limited only by the historical maximum flow. This rule holds even when the current reservoir level is below the $T D L$ :

$$
\begin{gathered}
Q_{\text {out }}=\operatorname{minimum}\left(Q_{10 \text { day }}, R V-I R V\right), \\
\quad \text { if } R L>I R L \text { and } R S<I V_{30 d}
\end{gathered}
$$

where

$$
\begin{gathered}
Q_{10 \text { day }} \quad \text { is the 10-day maximum measured outflow } \\
\text { from the reservoir, in acre-feet. }
\end{gathered}
$$

A description of each of these critical thresholds for each of the Canadian reservoirs is given in table 3 and shown in figure 6.

Similar to the releases from Canadian reservoirs, releases from Lake Darling are based on an IRL and the use of TDL (International Joint Commission, 1989, Annex A, plate A-4); however, release guidelines for Lake Darling change according to time of year (International Joint Commission, 1989). If the reservoir level is below the IRL but above the TDL, then during the months of March, April, and May, reservoir releases are capped at channel capacity $\left(2,500 \mathrm{ft}^{3} / \mathrm{s}\right.$, or about 23,500 acre-ft for a 10-day period); for the other months, reservoir releases are capped at $500 \mathrm{ft}^{3} / \mathrm{s}$. However, once the reservoir level is above the IRL, then the channel capacity is considered to be $2,500 \mathrm{ft}^{3} / \mathrm{s}$, no matter the month. For Lake Darling, the IRL was set at the full supply level (FSL) of $1,597 \mathrm{ft}$ given the elevation/capacity curves for this reservoir included values above FSL, unlike Boundary Reservoir, which only provided elevation/capacity values up to the FSL in Annex A. Additionally, the TDL for Lake Darling is determined through looking at uncontrolled 30-day streamflow volumes at the Souris River near Sherwood, N. Dak. (USGS streamgage 05114000, U.S. Geological Survey, 2017; fig. 1; hereafter referred to as "Sherwood Crossing"), and the use of
Annex A (International Joint Commission, 1989; Annex A, plate A-4). Uncontrolled volume at Sherwood Crossing is the volume of runoff that cannot be controlled by the available flood control storage (International Joint Commission, 1989).

\section{Streamflow Routing}

After determining the releases from the Canadian reservoirs, based on forecasted 30-day inflow volumes and the IRL, releases were routed down to Sherwood Crossing using the same 10-day streamflow routing model presented in Kolars and others (2016) with the lags represented by the fractions of current and previous 10-day streamflows and streamflow loss to evaporation and aquifer recharge shown in table 4. After flows are routed to Sherwood Crossing, routed flow volume and the target flow (TF) volume are compared. The TF volume was determined using forecasted natural 30-day streamflow volumes at Sherwood Crossing and Annex A (International Joint Commission, 1989; Annex A, plate A-5). The forecasted natural 30-day streamflow volume is the flow that would have happened if the reservoirs were not in place; these natural streamflow volumes were produced from the natural streamflow routing model in Kolars and others (2016). If the current routed streamflow volume (considering regulation) is greater than the TF volume, then the excess (that above the TF volume) is stored back in the reservoirs by reducing releases. When placing the excess volume back in the reservoirs, the reservoir with the largest available storage is filled first. During a flood, the maximum amount retained in the reservoir is equivalent to either the quantity of water required to fill the reservoir to the top of its maximum allowable flood level or the amount of water that had been released from the reservoir-whichever is less. If there is still excess flow to

\begin{tabular}{|c|c|c|c|c|c|}
\hline $\begin{array}{l}\text { Streamgage } \\
\text { identifier } \\
\text { (fig. 1) }\end{array}$ & Streamgage name & $\begin{array}{l}\text { State or } \\
\text { Province }\end{array}$ & $\begin{array}{c}\text { Fraction of } \\
\text { current } \\
\text { 10-day } \\
\text { streamflow }\end{array}$ & $\begin{array}{c}\text { Fraction of } \\
\text { previous } \\
10 \text {-day } \\
\text { streamflow }\end{array}$ & $\begin{array}{c}\text { Streamflow } \\
\text { loss, } \\
\text { in percent }\end{array}$ \\
\hline 05ND004 & Moose Mountain Creek near Oxbow & Saskatchewan & 1.0 & 0 & 0 \\
\hline 05NA003 & Long Creek at western crossing of international boundary & Saskatchewan & 1.0 & 0 & 0 \\
\hline 05113600 & Long Creek near Noonan & North Dakota & 0.80 & 0.20 & 5 \\
\hline $05 \mathrm{NB} 036$ & Souris River below Rafferty Reservoir & Saskatchewan & 0.80 & 0.20 & 5 \\
\hline 05114000 & Souris River near Sherwood & North Dakota & 0.90 & 0.10 & 0 \\
\hline 05116000 & Souris River near Foxholm & North Dakota & 1.0 & 0 & 0 \\
\hline 05116500 & Des Lacs River at Foxholm & North Dakota & 1.0 & 0 & 0 \\
\hline
\end{tabular}
be retained, then the reservoir with the next largest available

Table 4. Lags applied to 10-day streamflow routing model (from Kolars and others, 2016).

[NA, not available because of lack of reconstructed streamflow data] 
storage is filled in a similar manner as the first. After most, if not all, excess flow at Sherwood Crossing has been retained in the Canadian reservoirs, the updated releases from the reservoirs are routed again using the same streamflow routing model in Kolars and others (2016). If there is still excess after the last reservoir has been filled to its maximum allowable flood level, then the excess is allowed to flow through at Sherwood Crossing.

The updated flow volumes at Sherwood Crossing then are routed, using the streamflow routing model from Kolars and others (2016), and fed into Lake Darling as inflows. Lake Darling outflows (determined using the TDL and IRL as described in the "Reservoir Operation" section) then are routed down to Minot, N. Dak., using the same streamflow routing model as in Kolars and others (2016) but using Lake Darling outflows in place of natural streamflows at Souris River near Foxholm, N. Dak. (USGS streamgage 05116000; fig. 1). After streamflows have been routed down to Minot, N. Dak., streamflow volumes in excess of the channel capacity $\left(5,000 \mathrm{ft}^{3} / \mathrm{s}\right.$, or about 98,000 acre-ft for a 10-day period) are reduced by taking the excess volume and storing it back in Lake Darling. If Lake Darling is at its maximum allowable flood level, the excess is stored in the Canadian reservoirs following the same format as storing excess flows at Sherwood Crossing. If there still is excess flow after all the reservoirs have been filled, then the excess is allowed to flow through Minot in excess of $5,000 \mathrm{ft}^{3} / \mathrm{s}$. A schematic of the streamflow routing model is presented in figure 7, where (1) releases from the Canadian reservoirs are determined; (2) reservoir releases and intervening flows (according to the natural 10-day flow routing model described in Kolars and others [2016]) are routed down to Sherwood Crossing; (3) control point at Sherwood Crossing where routed flows from step 2 are compared with target flows provided in Annex A (International Joint Commission, 1989, plate $\mathrm{A}-5$ ) and adjusted according to the description given in the "Streamflow Routing" section of this report; (4) flows from Sherwood Crossing are routed to Lake Darling; (5) based on routed flows into Lake Darling and the TDL, Lake Darling Reservoir releases are determined; (6) Lake Darling releases are routed to Minot, N. Dak.; and lastly (7) routed flows to Minot, N. Dak., are compared with the channel capacity of $5,000 \mathrm{ft}^{3} / \mathrm{s}$ and adjusted according to the description given previously in the "Streamflow Routing" section of this report.

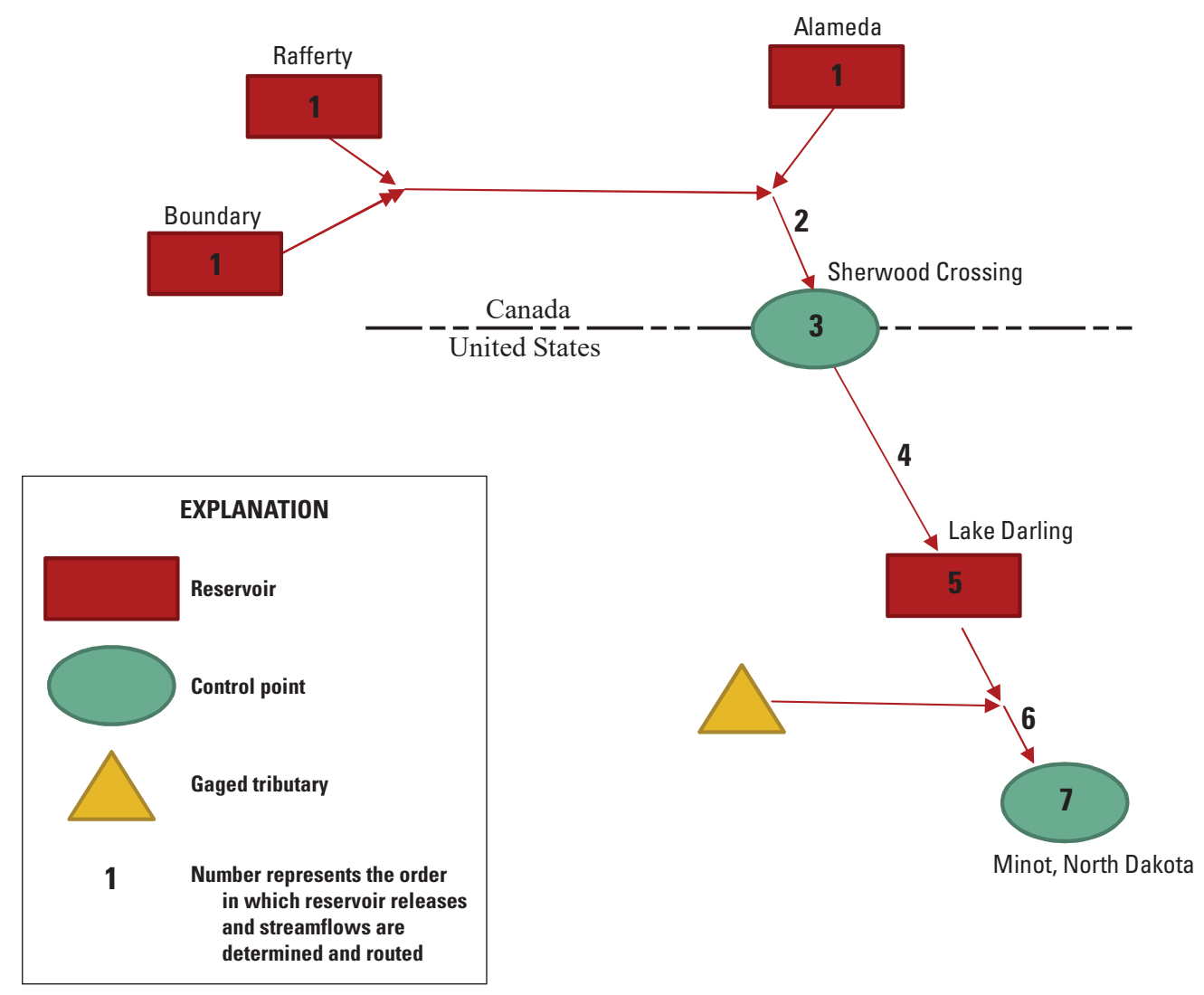

Figure 7. Regulated reservoir storage/streamflow routing model and the order in which streamflows are determined and routed down to Minot, North Dakota (Souris River above Minot, North Dakota; U.S. Geological Survey streamgage 05117500). 


\section{Regulated Reservoir Storage/Streamflow Routing Model Results}

A comparison of measured and simulated 10-day reservoir volumes for Rafferty, Alameda, and Boundary Reservoirs and Lake Darling is shown in figures 8, 9, 10, and 11, respectively. There was generally good agreement between the measured and simulated data for the four reservoirs. The correlation coefficients $(r)$ between measured and simulated reservoir volumes (table 5) ranged from $r=0.64$ for Alameda Reservoir to $r=0.96$ for Boundary Reservoir, and the root mean square error (RMSE) ranged from 4,412 acre-ft for Boundary Reservoir to 33,902 acre-ft for Rafferty Reservoir. For reservoir releases (table 6), the correlation coefficients ranged from $r=0.66$ for Alameda Reservoir to $r=0.99$ for Boundary Reservoir, and the RMSE ranged from 3,525 acre$\mathrm{ft}$ for Alameda Reservoir to 23,640 acre-ft for Lake Darling. The larger RMSE of the reservoir releases for Lake Darling probably result from larger differences between actual and forecasted 30-day inflow volumes for Lake Darling compared to the other reservoirs. For Lake Darling, Annex A (International Joint Commission, 1989) uses 30-day uncontrolled flows at Sherwood, N. Dak., instead of inflows at the reservoir structure. Given that measured and simulated reservoir levels at Lake Darling remained below the IRL for most of the calibration period (1992-2011), the amount released from the reservoir depended on the TDL, which depends on streamflows at the Sherwood crossing. Scenarios A and B in figure 6 represent the reservoir operation situation for Lake Darling during most of the calibration period. The lack of fit, with respect to replicating reservoir volumes, was somewhat expected given operation of Lake Darling depends on many factors, including wildlife management, flood protection, agriculture, and water supply. When comparing measured and simulated 10-day releases from the Canadian reservoirs, simulated values seemed to follow the same pattern as measured values, and periods of high and low flow were observed in the measured and simulated record, indicating that during high flow periods, using TDL partially compensated for the errors between measured and simulated reservoir volumes (figs. 8, 9, 10 , and 11).

After streamflow was routed through the regulated reservoir storage/streamflow routing model and excess flows were placed back in the reservoirs, simulated 10-day streamflows at Minot, N. Dak., were observed to visually follow the same pattern as historical flows (fig. 12) and had a correlation coefficient of 0.91 and RMSE of 1,184 ft $/ \mathrm{s}$ from 1992 through 2011. Similarly, simulated annual streamflow volumes at Minot, N. Dak., followed the same pattern as historical gaged (measured) volumes with overpredictions during the flood years of 1999, 2009, and 2011 and underpredictions during the flood years of 1995, 1996, 2005, and 2010 (fig. 13).

\section{Methods for Developing the Stochastic Regulated Streamflow Model}

The regulated reservoir storage/flow routing model described earlier in this report was combined with the stochastic natural streamflow model described in Kolars and others (2016) to provide a stochastic model for simulating regulated streamflow for the upper Souris River Basin. The simulated regulated streamflow data from the stochastic model were used to evaluate future flood risk. The methods used to simulate regulated streamflow and evaluate flood risk are described in this section, and flood risk results for the Souris River above Minot, N. Dak. (USGS streamgage 05117500) (fig. 1) are provided in the "Stochastic Simulation Results" section.

In the previous study, Kolars and others (2016) stochastically generated time series of potential future 10-day mean inflow volumes to the upstream reservoirs (Boundary, Alameda, and Rafferty), and incremental flow volumes for subbasins downstream from the reservoirs and upstream from the Souris River above Minot, N. Dak. (USGS streamgage 05117500) (fig. 1), were used as inputs to a natural (unregulated) streamflow routing model to generate time series of natural 10-day mean streamflow for streamgages at the terminus of each subbasin. The same generated reservoir inflow volumes and downstream incremental flow volumes from Kolars and others (2016) were used as inputs to the reservoir storage/flow routing model described in the "Methods for Developing the Regulated Reservoir Storage/streamflow Routing Model" section of this report to generate time series of regulated 10-day mean streamflow for the same streamgages. These generated time series are referred to as "traces." There were 100 traces generated for each streamgage, each 100 years long. As in the previous report, starting conditions (initial reservoir storage volumes and soil moisture storage conditions) for each trace were generated at random by discarding values for a 10 -year initialization period at the beginning of each trace. Each trace assumes 50 years of wet (similar to 1970-2017) climatic conditions followed by 50 years of dry (similar to 1912-69) climatic conditions; thus, there are a total of 10,000 simulation years $(5,000$ for the wet period and 5,000 for the dry period). Note that although each trace is generated assuming a 50 -year wet period followed by a 50 -year dry period, no assumption is made regarding when the current wet state (beginning in 1970) actually will end. Furthermore, using a 100-year simulation period is not related to the expected design life of potential flood control projects being considered. The lengths of the wet and dry periods simply were chosen to represent long enough periods to provide an ample number of simulation years for estimating flood magnitudes corresponding to small annual exceedance probabilities (for example, 1 percent or less).

An example of the natural (unregulated) and regulated 10-day mean flows for the Souris River above Minot, N. Dak. (USGS streamgage 05117500), for one of the traces (trace number 23) is shown in figure 14. The maximum recorded 10-day mean streamflow for this streamgage for the historical 


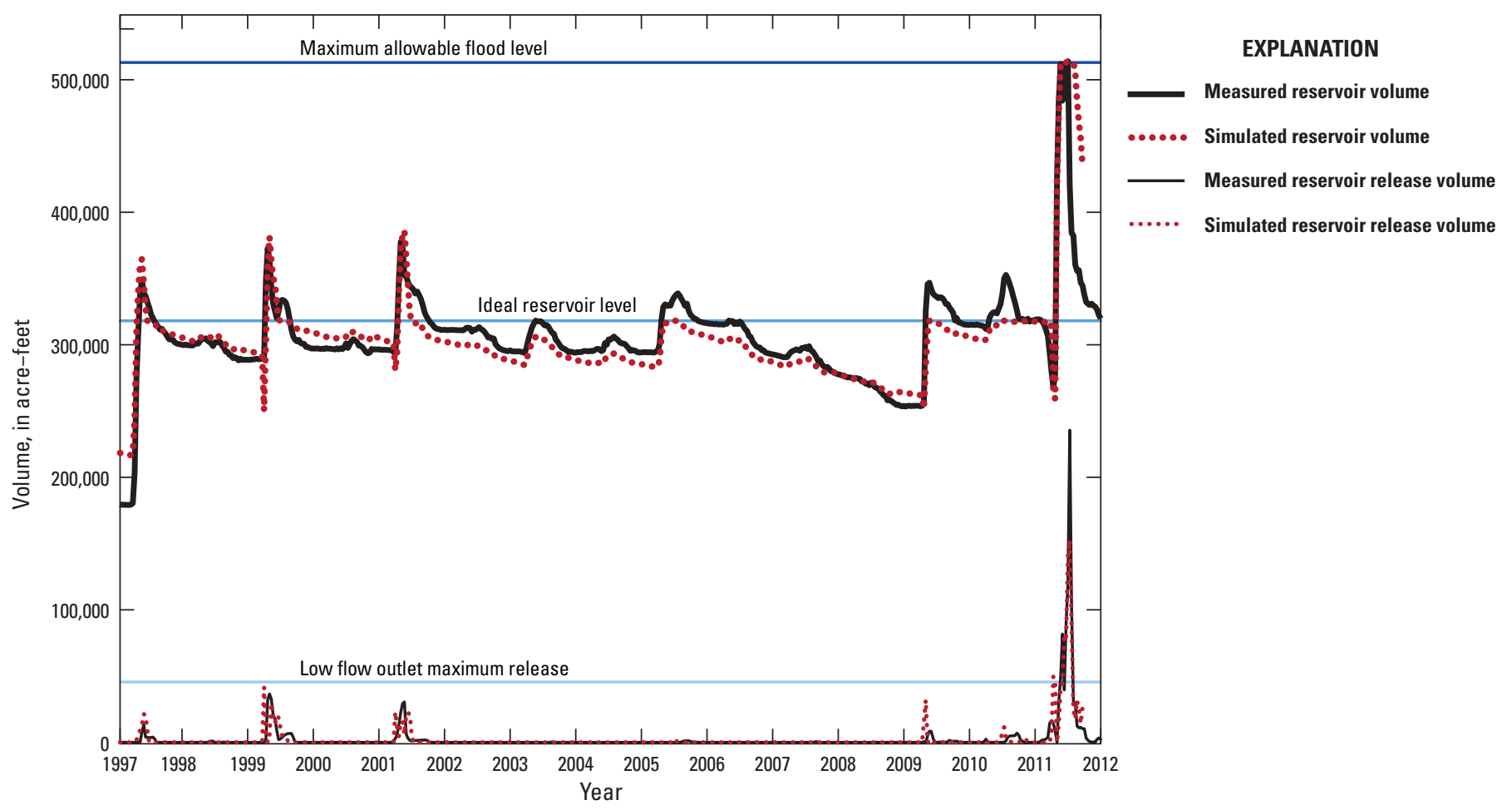

Figure 8. Comparison of measured and simulated reservoir volumes and releases (outflows) for Rafferty Reservoir from 1997 (when the reservoir first filled to full supply level) through 2011.

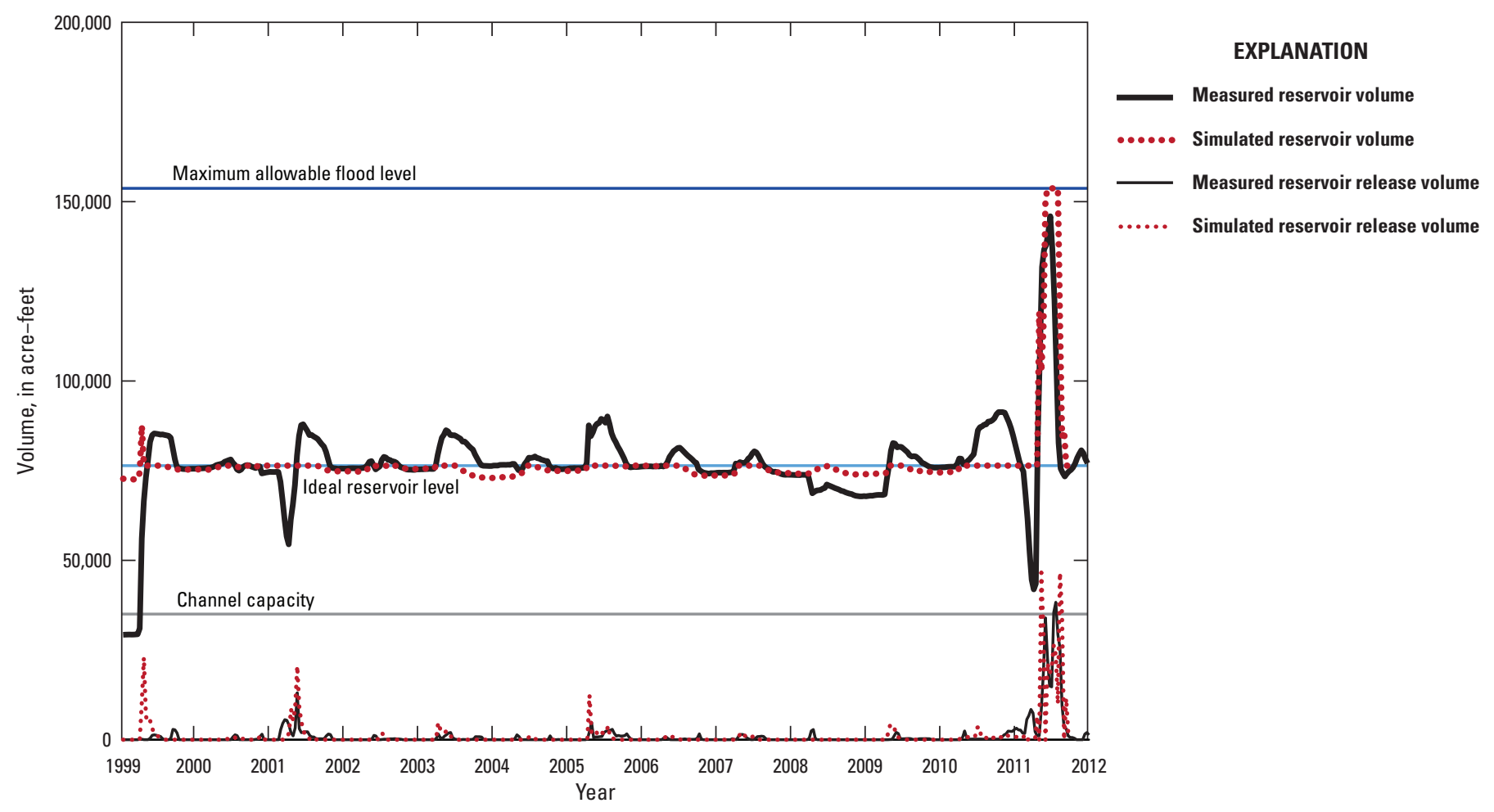

Figure 9. Comparison of measured and simulated reservoir volumes and releases (outflows) for Alameda Reservoir from 1999 (when the reservoir first filled to full supply level) through 2011. 


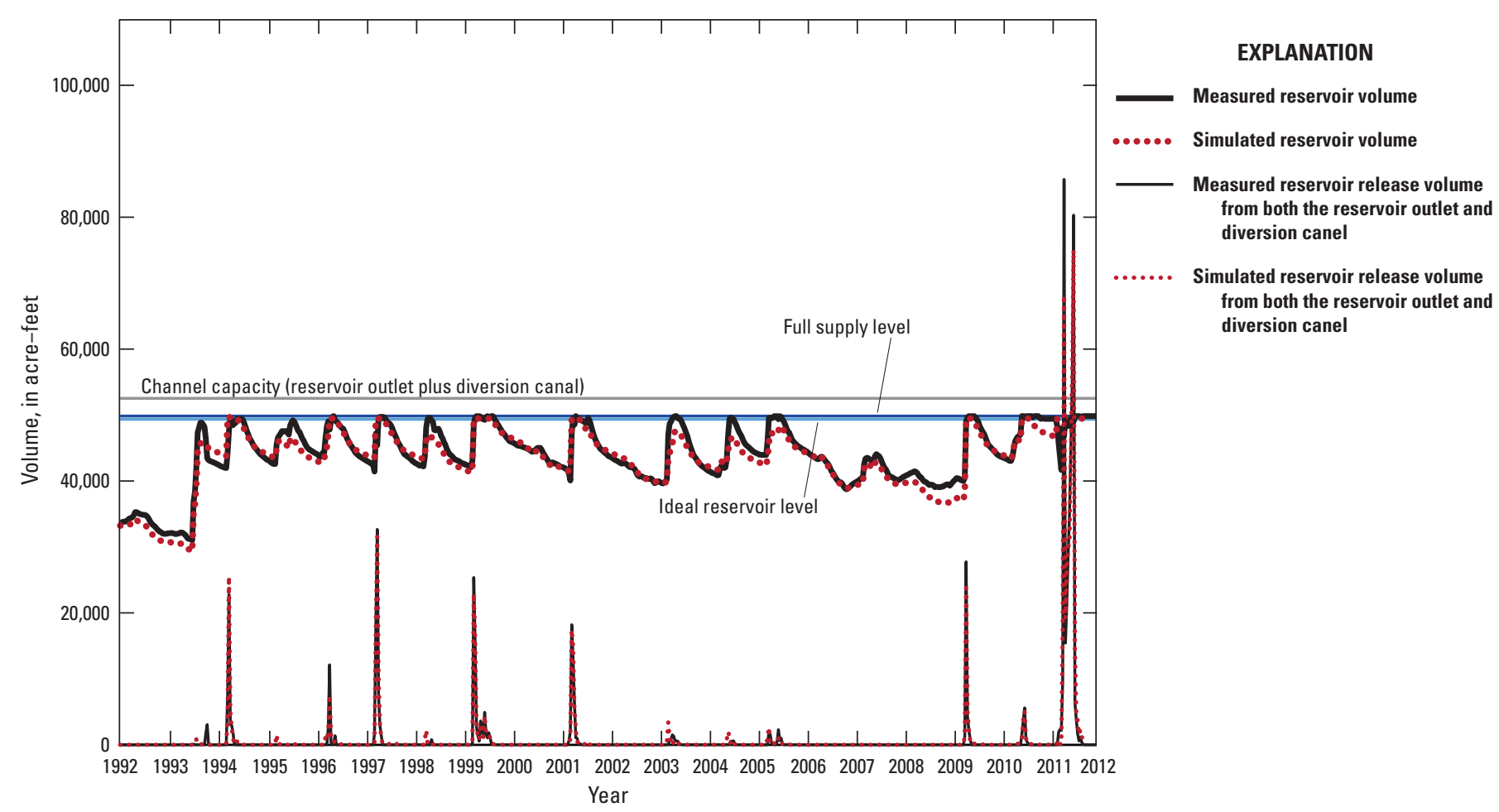

Figure 10. Comparison of measured and simulated reservoir volumes and releases (outflows) for Boundary Reservoir from 1992 through 2011.

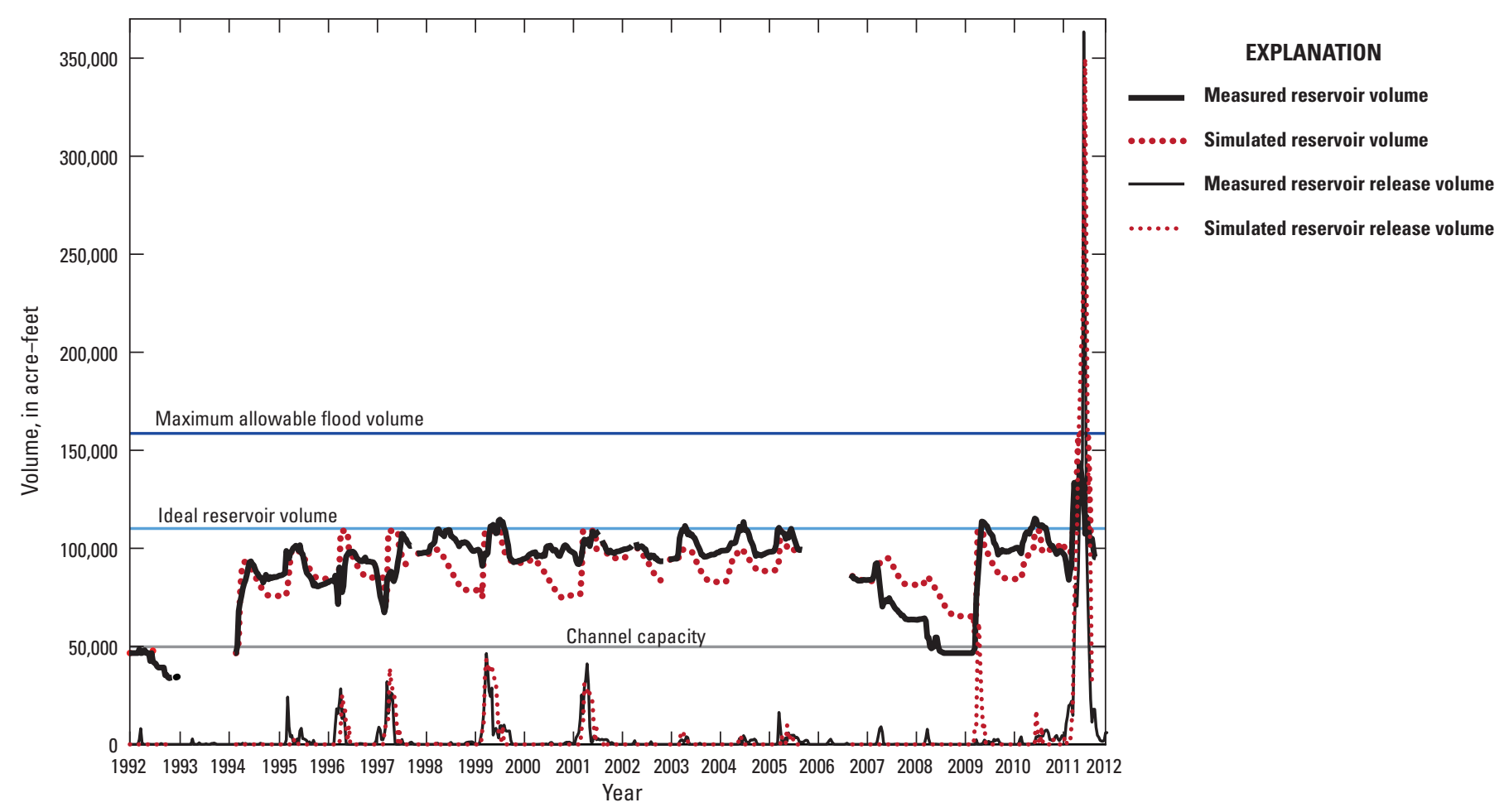

Figure 11. Comparison of measured and simulated reservoir volumes and releases (outflows) for Lake Darling from 1992 through 2011. 
Table 5. Correlation coefficients and root mean square error between measured and simulated 10-day mean reservoir volumes for Rafferty, Alameda, and Boundary Reservoirs and Lake Darling.

[RMSE, root mean square error]

\begin{tabular}{lccr}
\hline \multicolumn{1}{c}{ Reservoir } & $\begin{array}{c}\text { Maximum } \\
\text { allowable } \\
\text { flood level, } \\
\text { in acre-feet }\end{array}$ & $\begin{array}{c}\text { Correlation } \\
\text { coefficient }\end{array}$ & $\begin{array}{c}\text { RMSE, } \\
\text { in acre- } \\
\text { feet }\end{array}$ \\
\hline Rafferty (1997-2011) & 513,000 & 0.87 & 33,902 \\
Alameda (1999-2011) & 153,710 & 0.64 & 8,783 \\
Boundary (1992-2011) & 49,800 & 0.96 & 4,412 \\
Lake Darling (1992-2011) & 158,600 & 0.77 & 16,445 \\
\hline
\end{tabular}

Table 6. Correlation coefficients and root mean square error between measured and simulated 10-day mean reservoir releases for Rafferty, Alameda, and Boundary Reservoirs and Lake Darling.

[RMSE, root mean square error]

\begin{tabular}{lccc}
\hline \multicolumn{1}{c}{ Reservoir } & $\begin{array}{c}\text { Channel } \\
\text { capacity, in } \\
\text { acre-feet }\end{array}$ & $\begin{array}{c}\text { Correlation } \\
\text { coefficient }\end{array}$ & $\begin{array}{c}\text { RMSE, } \\
\text { in acre- } \\
\text { feet }\end{array}$ \\
\hline Rafferty (1997-2011) & $\begin{array}{r}9,917 \\
145,531\end{array}$ & 0.88 & 12,487 \\
\hline Alameda (1999-2011) & 35,703 & 0.66 & 3,525 \\
\hline Boundary (1992-2011) & 17,851 & 0.99 & 5,782 \\
\hline Lake Darling (1992-2011) & 49,587 & 0.90 & 23,640 \\
\hline
\end{tabular}

${ }^{1}$ In the model, the capacity of Rafferty Reservoir's low-flow outlet was used in place of the downstream reservoir channel capacity.

period of record (1904-2017) was in 2011 and was about $18,000 \mathrm{ft}^{3} / \mathrm{s}$ (U.S. Geological Survey, 2017). For this particular trace, there were 3 years during the wet period and 1 year during the dry period when the simulated natural flow exceeded the 2011 record. Regulation generally resulted in a large reduction in the annual maximum flow compared to unregulated flow except for a single year during the wet period for which the regulated maximum flow was about twice as high as the 2011 record. An example of another trace (number 66) is shown in figure 15. For this trace, there were 3 years during the wet period for which unregulated flow exceeded the 2011 record compared to no exceedances for the dry period. When looking at regulated flows, there was 1 year during the wet period that was slightly higher than the 2011 record. Note that because extremely high 30 -day inflow volumes to the upstream reservoirs in the spring of 2011 caused reservoir outflows to be at maximum allowable levels, the maximum unregulated flow for 2011 would have been similar to the recorded, historical maximum regulated flow during 2011. However, as indicated by trace 66 , there can be simulation years when the maximum unregulated flows exceeded the 2011 value, but the maximum regulated flow was reduced substantially compared to the unregulated flow because the 30-day inflow volumes and corresponding reservoir releases for one or more of the upstream reservoirs were less than the 2011 values.

The annual maximum 10-day mean streamflow was computed for each of the 10,000 simulation years and for unregulated and regulated conditions. The resulting annual maxima were used to estimate flood magnitudes associated with specified annual exceedance probabilities, which is called a flood frequency analysis. A flood frequency analysis was completed assuming three conditions:

- Condition A, wet equilibrium.-Flood frequency estimates based on the first 50 years of each trace (5,000 simulation-years). This condition represents flood risk for the remaining duration of the current (1970-2017) wet period.

- Condition B, transition.-Flood frequency estimates based on years 26-75 of each trace (5,000 simulation years). This condition represents flood risk during the transition period between the end of the current wet period and start of the subsequent dry period.

- Condition C, dry equilibrium.-Flood frequency estimates based on years $51-100$ of each trace $(5,000$ simulation years). This condition represents flood risk during a prolonged period of dry conditions (similar to 1912-69).

It is not possible to predict when the current (1970-2017) wet climatic conditions may revert back to drier conditions similar to 1912-69. The flood frequency curves for the three conditions are meant to bracket the range of reasonable possibilities. Based on climate modeling and paleolake-level information for the Devils Lake Basin (just east of the Souris Basin in northeastern North Dakota), Vecchia (2011) determined that, starting from any given initial year during a wet state (such as 2016), there was about a 70-percent chance of the wet climatic conditions continuing at least 10 more years (at least until 2026) and about a 40-percent chance of the wet climate state continuing at least 30 more years (at least until 2046). Furthermore, wet soil moisture conditions and a tendency for high runoff in the basin may persist for as much as 10 years after the transition back to drier climatic conditions. Therefore, mean annual flood risk during the next 25 years (2016-40) may be represented best by climatic condition A, which represents equilibrium conditions for the wet (similar to 1970-2017) climate state. The curve for climatic condition $\mathrm{B}$ represents mean annual flood risk for the next 50 years (2016-65) under a hypothetical scenario in which the wet conditions persist for an additional 25 years (2016-40) before reverting back to dry conditions (similar to 1912-69) for the next 25 years (2041-65). However, the curve for climatic condition $\mathrm{B}$ would tend to underestimate flood risk during the earlier years (2016-40) and overestimate flood risk during the 


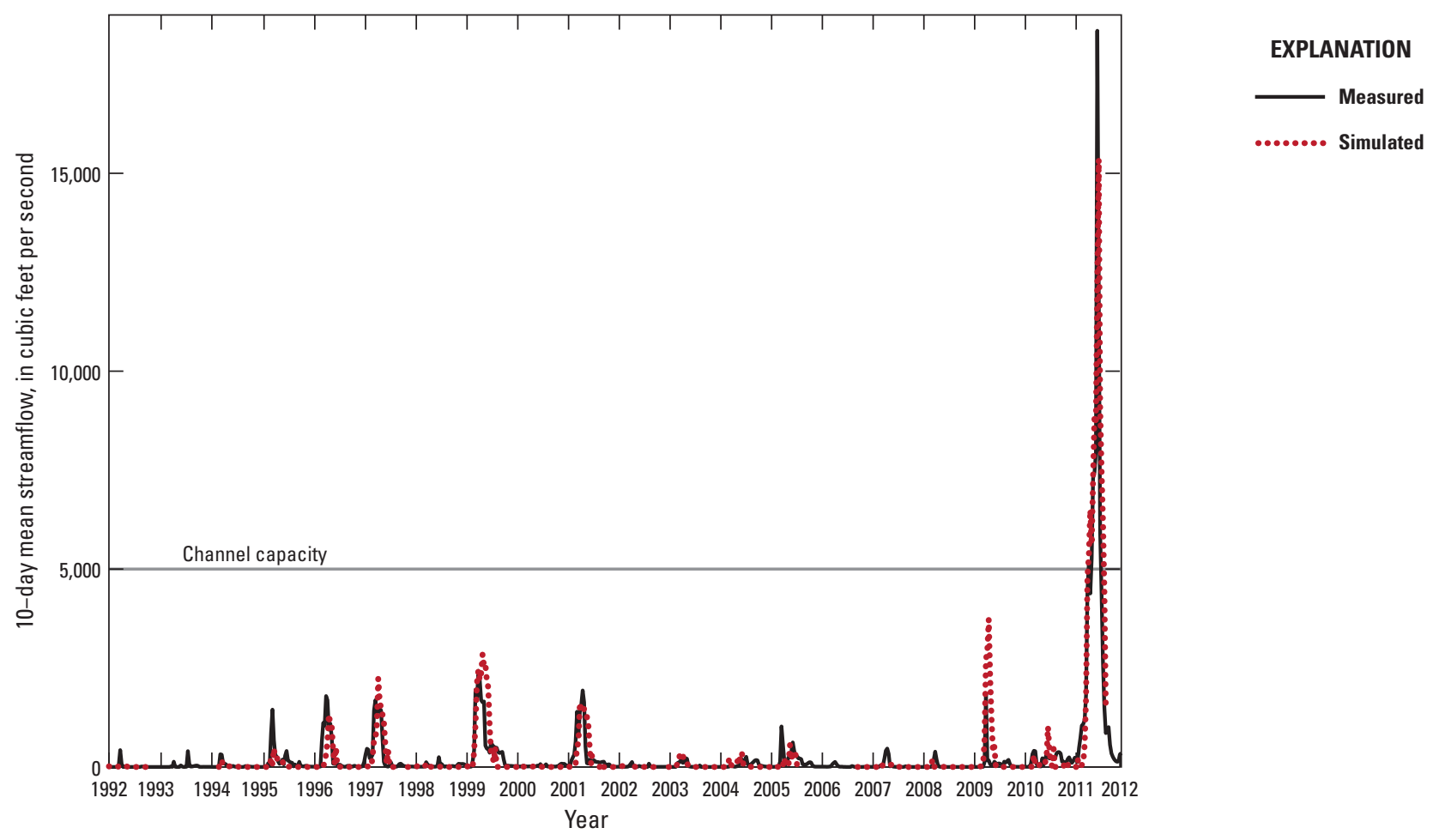

Figure 12. 10-day mean measured and simulated streamflow at Souris River above Minot, North Dakota (U.S. Geological Survey streamgage 05117500), 1992-2011.

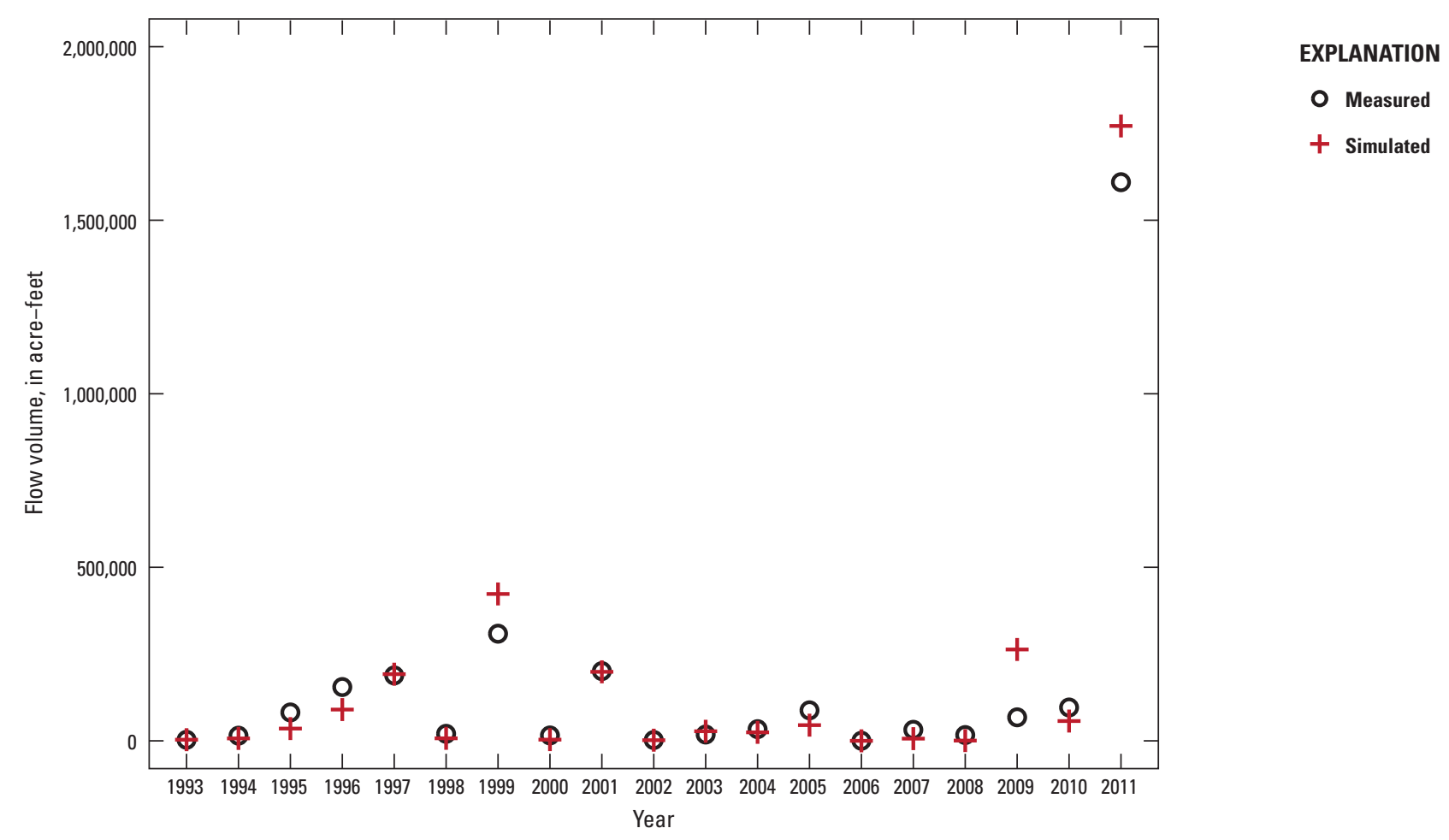

Figure 13. Annual measured and simulated streamflow volumes at Souris River above Minot, North Dakota (U.S. Geological Survey streamgage 05117500), 1993-2011. 
Trace 23
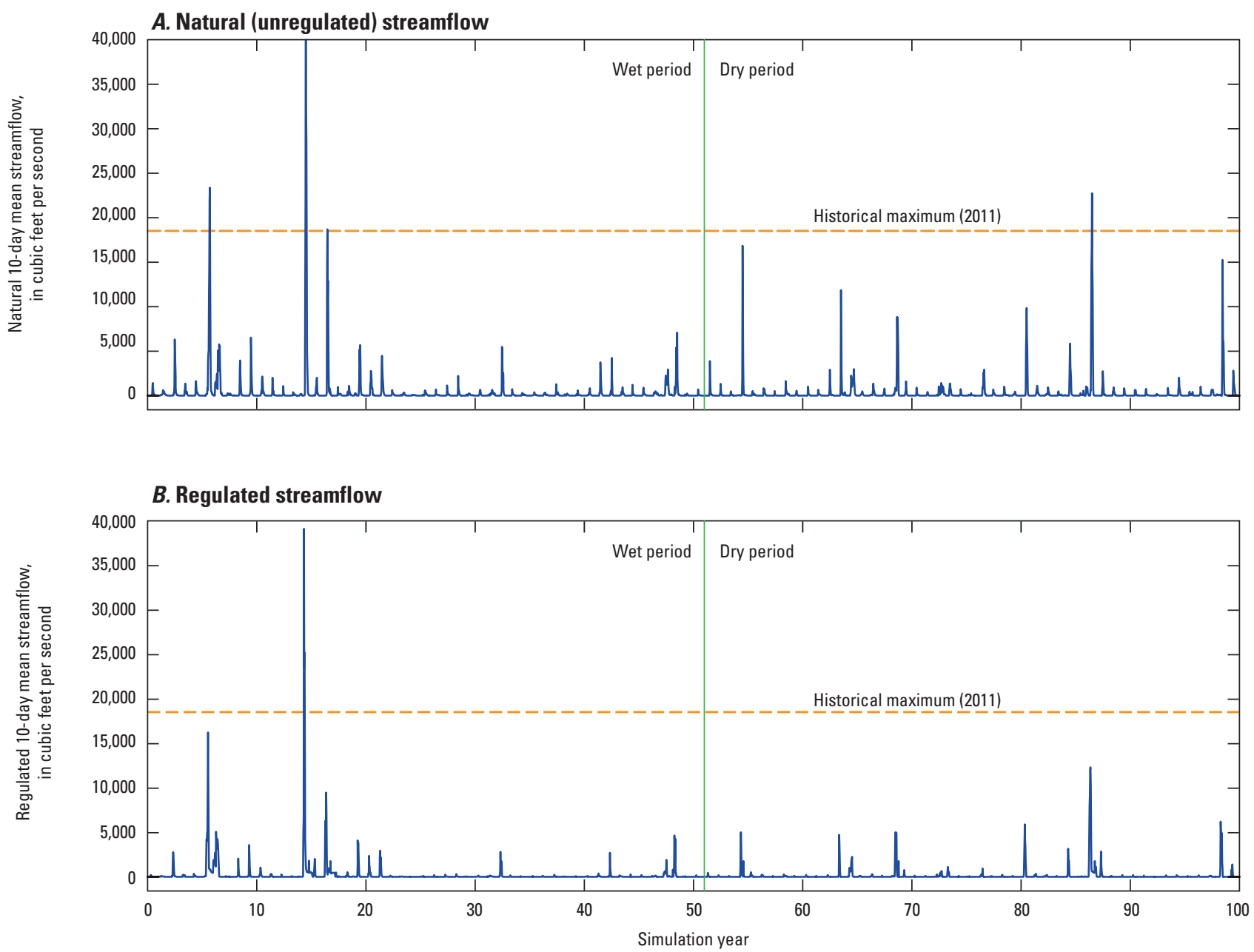

Figure 14. Simulated 10-day mean streamflow for 100-year simulation period (50 years of wet climate state followed by 50 years of dry climate state) for the Souris River above Minot, North Dakota (U.S. Geological Survey streamgage 05117500) (stochastic trace 23). $A$, natural (unregulated) flow; and $B$, regulated flow. 
Trace 66
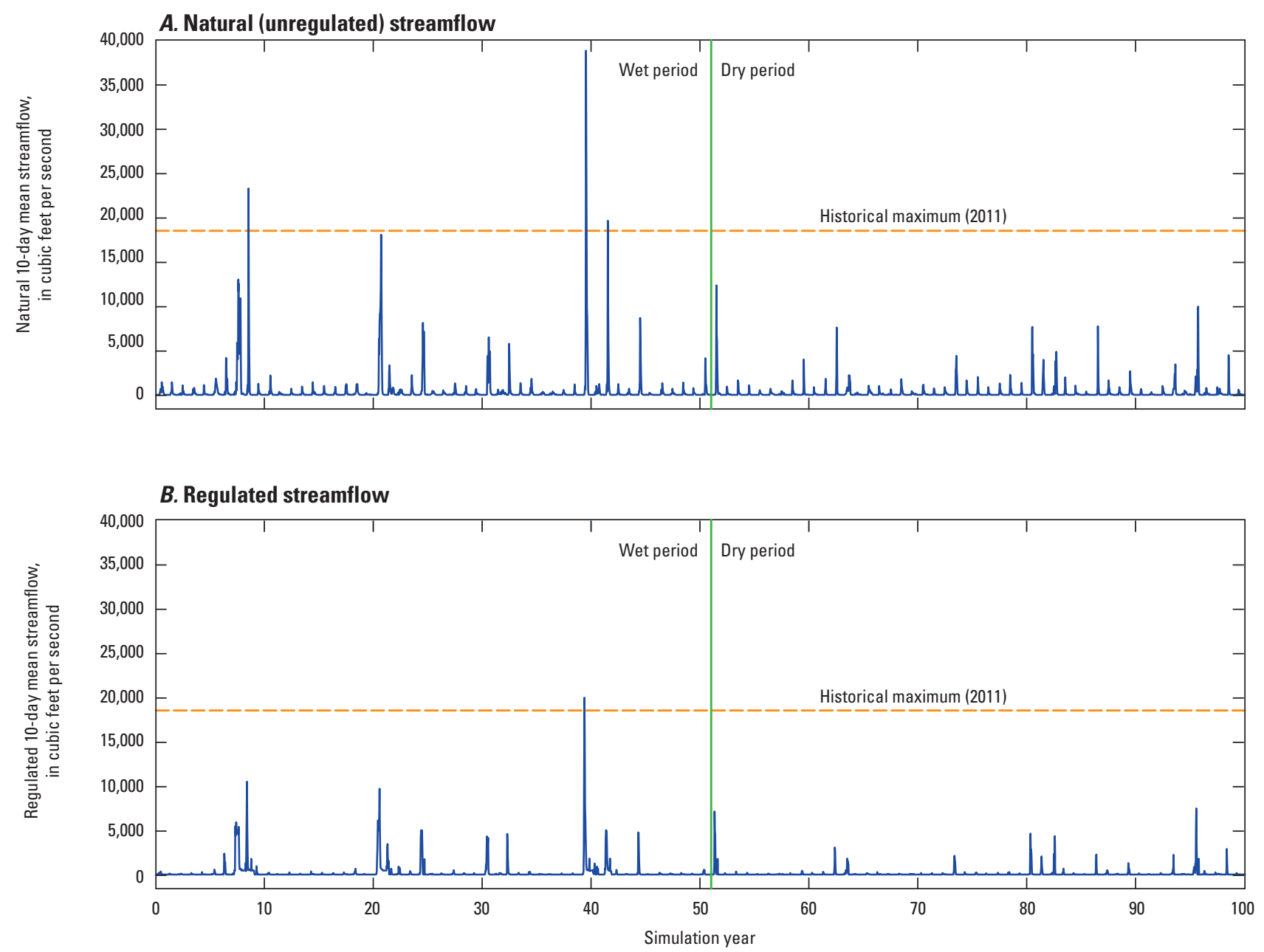

Figure 15. Simulated 10-day mean streamflow for 100-year simulation period ( 50 years of wet climate state followed by 50 years of dry climate state) for the Souris River above Minot, North Dakota (U.S. Geological Survey streamgage 05117500) (stochastic trace 66). $A$, natural (unregulated) flow; and $B$, regulated flow. 
later years (2041-65) and thus may not represent the actual flood risk very well in either period. The curve for climatic condition $\mathrm{C}$ represents mean annual flood risk during the next 50 years (2016-65) under a hypothetical scenario in which drier climatic conditions return immediately (2016) and persist for at least 50 years, and thus would even more severely underestimate flood risk during the earlier years (2016-40) compared to climatic condition B.

Flood frequency estimates for design of levees and other critical infrastructure are based on the annual maximum instantaneous flow, or annual peak streamflow, whereas the simulations described in the previous paragraph are based on the annual maximum 10-day mean streamflow. Flood frequency values for a generic year are defined as follows:

$$
\operatorname{Prob}\left[A P F>A P F_{p}\right]=\operatorname{Prob}\left[A M 10 D F>A M 10 D F_{p}\right]=p / 100,
$$

where

$A P F \quad$ is annual peak streamflow, in cubic feet per second;

$A M 10 D F \quad$ is annual maximum 10-day mean streamflow, in cubic feet per second;

Prob[.] denotes probability;

is a specified exceedance probability, in percent;

$A P F_{p} \quad$ is the flood magnitude for annual peak streamflow corresponding to exceedance probability $p$, in cubic feet per second; and

$A M 10 D_{p} \quad$ is flood magnitude for annual maximum 10-day mean streamflow corresponding to exceedance probability $p$, in cubic feet per second.

The annual peak streamflow $(A P F)$ is always greater than annual maximum 10-day mean streamflow $(A M 10 D F)$; consequently, the flood magnitude for annual peak streamflow corresponding to exceedance probability $p\left(A P F_{p}\right)$ will be greater than the flood magnitude for annual maximum 10-day mean streamflow corresponding to exceedance probability $p\left(A M 10 D_{p}\right)$ for all values of $p$. An empirical method was therefore used to increase estimates of $A M 10 D_{p}$ to "equivalent" estimates for $A P F_{p}$. The empirical method is based on the percent difference between recorded values of $A P F$ and $A M 10 D F$ :

$$
P D=100(A P F-A M 10 D F) / A M 10 D F,
$$

where

$$
\begin{gathered}
P D \quad \text { is the percent difference between } A P F \text { and } \\
A M 10 D F .
\end{gathered}
$$

The relations between $A M 10 D F$ and the percent difference between the annual peak streamflow and the annual maximum 10-day mean streamflow $(P D)$ for the Souris River above Minot, N. Dak. (USGS streamgage 05117500, fig. 1) and the Souris River near Sherwood, N. Dak. (USGS streamgage 05114000 , fig. 1 ) are shown in figure 16 . Only points for which $A M 10 D F$ was greater than or equal to
$1,000 \mathrm{ft}^{3} / \mathrm{s}$ were used in this analysis. The historical period of record is 1937-2016 for Sherwood Crossing and 1904-2016 for the USGS streamgage Souris River above Minot, N. Dak. (U.S. Geological Survey, 2017). The lines show the fitted geometric mean (an estimate of the median $P D$ as a function of $A M 10 D F)$ for each streamgage. The equations for each line were determined by fitting a weighted simple linear regression model (Helsel and Hirsch, 2002) for logarithm-transformed $P D$ given logarithm-transformed $A M 10 D F$ for the respective streamgages. The equation for the Souris River above Minot, N. Dak., (USGS streamgage 05117500) is given by

$$
\begin{gathered}
F V[\log (P D)]=0.82+0.56\{\log (A M 10 D F)-3\} ; \\
A M 10 D F \geq 1,000 \mathrm{ft}^{3} / \mathrm{s}
\end{gathered}
$$

and the equation for the Souris River near Sherwood, N. Dak., (USGS streamgage 05114000) is given by

$$
\begin{gathered}
F V[\log (P D)]=1.24+0.45\{\log (A M 10 D F)-3\} ; \\
A M 10 D F \geq 1,000 \mathrm{ft}^{3} / \mathrm{s}
\end{gathered}
$$

where

$F V[\log (P D)] \quad$ is the fitted value of logarithm-transformed percent difference; and

$\log () \quad$ is the base- 10 logarithm.

Weighted least-squares regression (Helsel and Hirsch, 2002) was used to estimate the coefficients in equations 7 and 8 because the variance of the regression residuals decreased as $A M D 10 F$ increased. The weights were the same for both equations and were given by

$$
W=1+[\log (A M 10 D F)-3]^{2}
$$

where

$W \quad$ is the weight used for the weighted leastsquares regression.

For example, the weight for $A M 10 D F=10,000 \mathrm{ft}^{3} / \mathrm{s}(W=2)$ is twice as large as the weight for $A M 10 D F=1,000 \mathrm{ft}^{3} / \mathrm{s}(W=1)$. Although there was a lot of scatter in the points, there was a highly significant ( $p$-value less than 0.01 ) increase in the geometric mean for both streamgages. Based on the good agreement with recorded flows for years with $A M 10 D F>2,000$ $\mathrm{ft}^{3} / \mathrm{s}$ (regardless of regulated conditions), the curves provided a reasonable approximation to $P D$ for $A M 10 D F>2,000 \mathrm{ft}^{3} / \mathrm{s}$. Because of the similarity between the curves for the two streamgages and the apparent temporal consistency of the relations despite differing regulated conditions during the historical period, it was assumed that the relation between $P D$ and $A M 10 D F$ is not affected by regulated conditions for $A M 10 D F>2,000 \mathrm{ft}^{3} / \mathrm{s}$.

Estimated flood frequency curves for the USGS streamgage Souris River above Minot, N. Dak., for specified exceedance probabilities were computed as follows. The estimated flood magnitude for $A M 10 D F\left(A M 10 D F_{p}\right.$ in eq. 5) is equal to the $100(1-p / 100)$ th percentile of the simulated annual maxima for all 5,000 simulation years (for each of the 


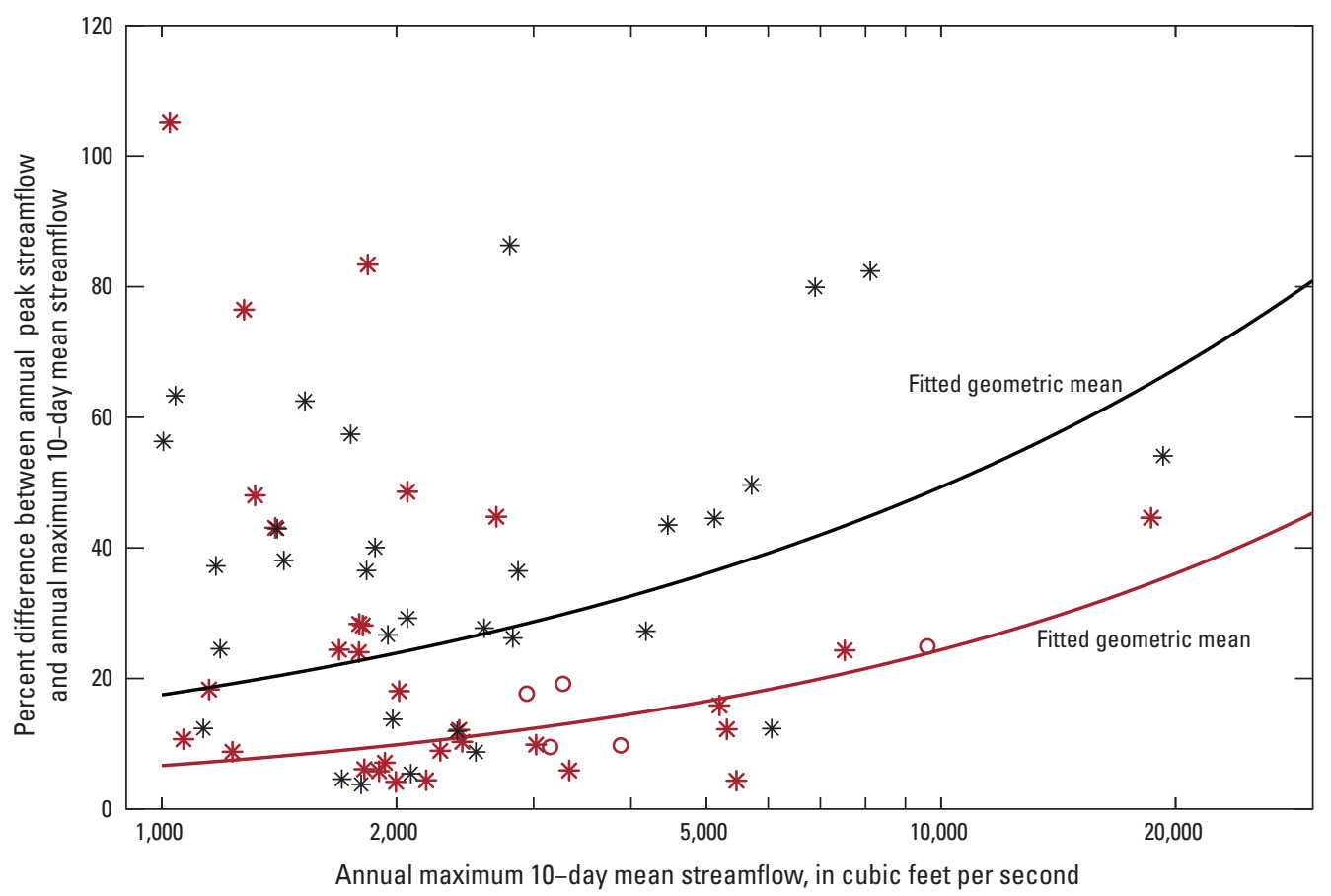

\section{EXPLANATION}

* Sherwood, 1937-2016

* Minot, 1937-2016

O Minot, $1904-36$

Figure 16. Difference between recorded annual peak streamflow and recorded annual maximum 10-day mean streamflow, as a percent of annual maximum 10-day mean streamflow, for the streamgages Souris River above Minot, North Dakota (U.S. Geological Survey streamgage 05117500), and Souris River near Sherwood, North Dakota (U.S. Geological Survey streamgage 05114000). [Period of record 1937-2016 for Sherwood streamgage and 1904-2016 for Minot streamgage; points for which annual maximum 10-day mean streamflow is less than 1,000 cubic feet per second are not shown.]

climatic conditions A-C). The estimated flood magnitudes for $A M 10 D F$ for regulated conditions were adjusted using equation 7 to obtain estimated flood magnitudes for $A P F$, namely

$$
\begin{gathered}
A P F_{p}=A M 10 D F_{p}\left(1+(0.01) 10^{\left[0.82+0.56\left\{\log \left(A M 10 D F_{p}\right)-3\right\}\right]}\right) \\
A M 10 D F_{p} \geq 1,000 \mathrm{ft}^{3} / \mathrm{s} .
\end{gathered}
$$

The flood frequency analysis results for all three conditions are described in the following section.

\section{Stochastic Simulation Results}

Estimated flood frequency curves for both unregulated and regulated annual maximum 10-day mean streamflow for the Souris River above Minot, N. Dak. (USGS streamgage 05117500), and exceedance probabilities less than 10 percent are shown in figure 17. For all three potential future climatic conditions, there were large reductions in the curves for regulated streamflow compared to unregulated streamflow. The largest reductions were for moderate (5-percent to 1-percent) exceedance probabilities; for example, for the 3-percent exceedance probability and condition A (wet equilibrium), the unregulated flood magnitude was about $16,000 \mathrm{ft}^{3} / \mathrm{s}$, compared to about $6,000 \mathrm{ft}^{3} / \mathrm{s}$ for the regulated flood magnitude, a reduction of about 60 percent.
The reductions were less (in relative terms) for the extreme (less than 1-percent) exceedance probabilities. For example, for the 0.2-percent exceedance probability and condition A, the unregulated flood magnitude was about $38,000 \mathrm{ft}^{3} / \mathrm{s} \mathrm{com}$ pared to about $21,000 \mathrm{ft}^{3} / \mathrm{s}$ for the regulated flood magnitude, a reduction of about 45 percent. A comparison among the regulated curves for the three future climatic conditions indicates that the regulated curves were most sensitive to the future climatic conditions for the more extreme exceedance probabilities. For example, for the 1-percent exceedance probability, the regulated flood magnitude for condition A (wet equilibrium) was about $12,500 \mathrm{ft}^{3} / \mathrm{s}$ compared to about $7,000 \mathrm{ft}^{3} / \mathrm{s}$ for condition $\mathrm{C}$ (dry equilibrium), a reduction of about 44 percent.

The estimated regulated frequency curves for annual maximum 10-day flows shown in figure 17 were adjusted using equation 10 to obtain estimated regulated frequency curves for annual peak streamflow. The resulting curves are shown in figure 18. For comparison purposes, the 11 largest recorded annual peak streamflows for the Souris River above Minot, N. Dak. (USGS streamgage 05117500; U.S. Geological Survey, 2017), for 1904-2016 are plotted as well. The plotting positions for the recorded peaks use the empirical (Weibull) exceedance probabilities $p=100 K /(n+1)$, where $K$ denotes the $K$ th largest recorded peak flow and $n=113$ is the record length (Helsel and Hirsch, 2002). Note that the recorded annual peak 

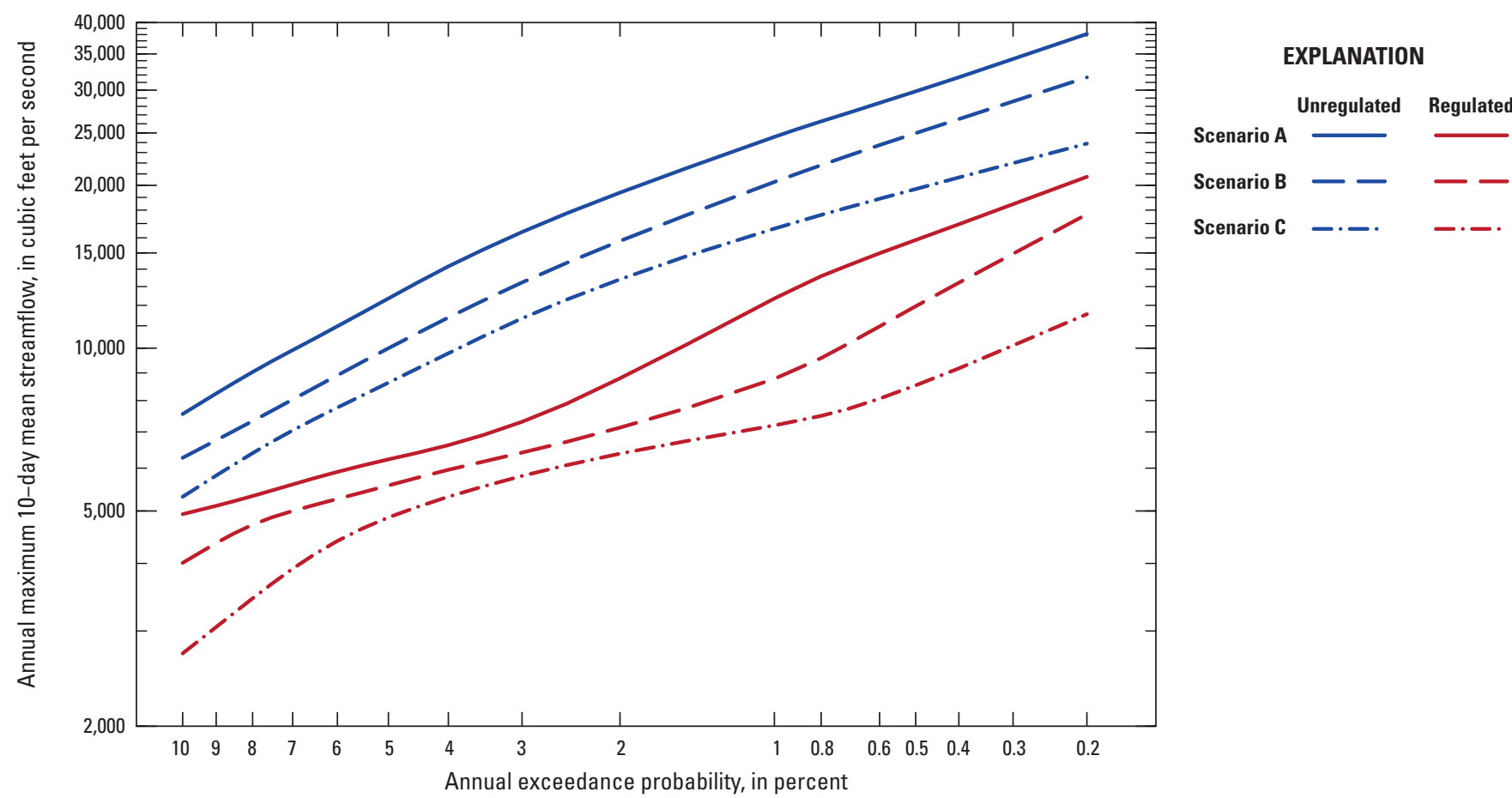

Figure 17. Estimated flood frequency curves for annual maximum 10-day mean streamflow for the Souris River above Minot, North Dakota (U.S. Geological Survey streamgage 05117500), for natural (unregulated) and regulated conditions and three climatic conditions. Scenario A, (wet equilibrium) representing wet (similar to 1970-2017) climatic conditions; scenario B, (transition) representing transition from wet to dry (similar to 1913-69) climatic conditions; and scenario C, (dry equilibrium) representing dry climatic conditions.

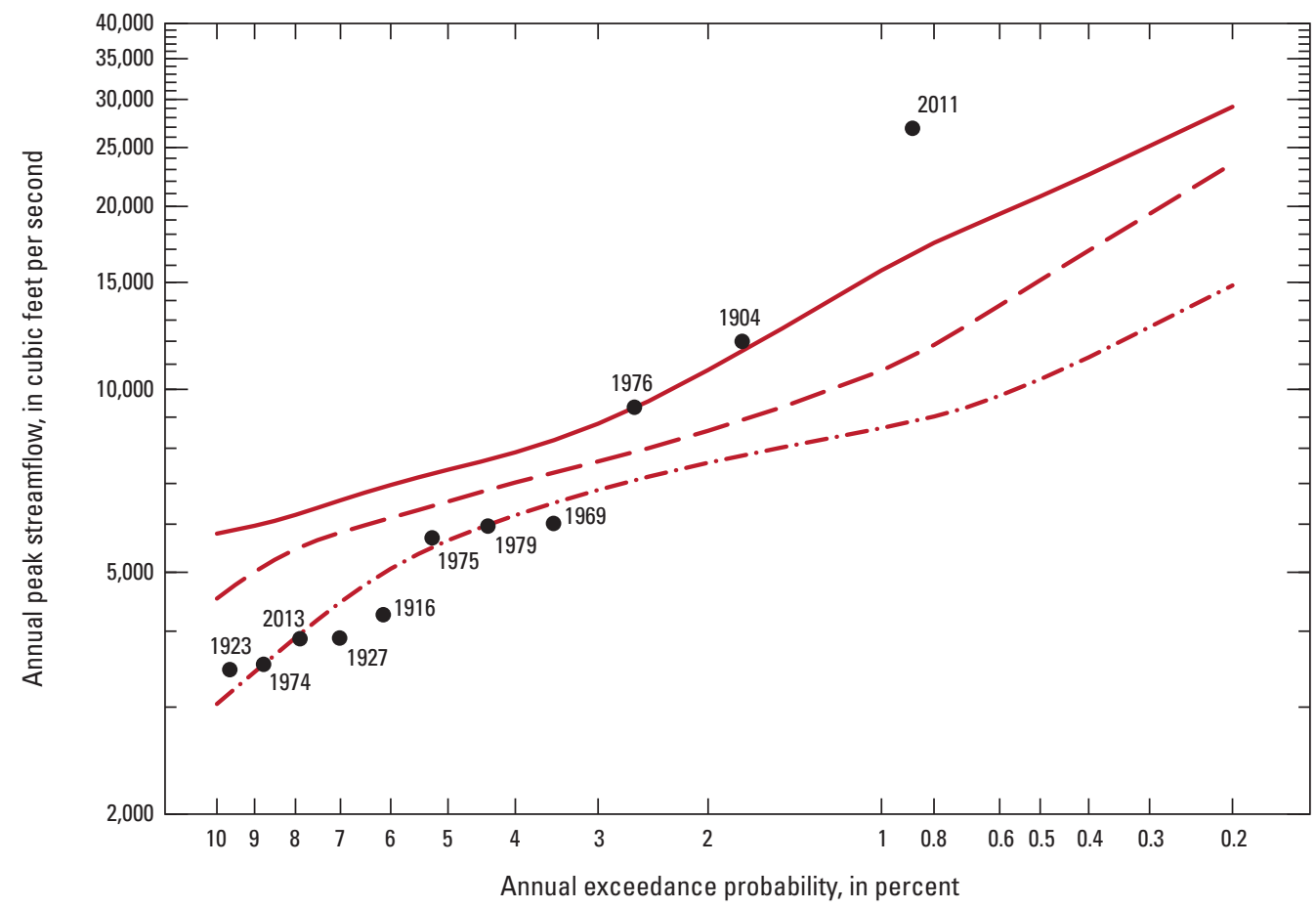

\section{EXPLANATION}

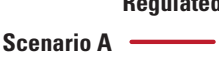

Scenario B - -

Scenario C - - -

Figure 18. Estimated flood frequency curves for annual instantaneous peak streamflow for the Souris River above Minot, North Dakota (U.S. Geological Survey streamgage 05117500), for regulated conditions and three future climatic conditions. Scenario A, (wet equilibrium) representing wet (similar to 1970-2017) climatic conditions; scenario B, (transition) representing transition from wet to dry (similar to 1913-69) climatic conditions; and scenario C, (dry equilibrium) representing dry climatic conditions. [The 11 largest recorded peak flows for 1904-2017, regardless of regulated conditions, are plotted using empirical (Weibull) probability plotting positions. Note that the regulated frequency curves assume future reservoir operation is the same as current (1991-2017) operation.] 
streamflows are shown regardless of past regulated conditions and have not been adjusted to represent current (1991-2017) regulation, whereas the estimated regulated curves are assuming current regulated conditions. For example, although the recorded annual peak streamflow for 1904 was the second highest peak of record, if the current reservoirs were in place during 1904, that point would be shifted down (and possibly to the left, depending on where it ranked among the other peak streamflows). The peak streamflow for 1976 also would be shifted down (and possibly to the left) had Rafferty and Alameda Dams been in place at that time. Only 2 of the 11 highest peak streamflows (2011 and 2013) happened after all the reservoirs were in place. The 2011 peak streamflow plots well above even the condition A curve, indicating that it was an extreme flood (exceedance probability well below 1 percent) even in context of the recent wet conditions.

As described previously in the "Review of Stochastic Natural (Unregulated) Streamflow Model" section of this report, there is believed to have been a transition in about 1970 from a period of drier climatic conditions to wetter climatic conditions, resulting in a higher risk of extreme floods, similar to the 2011 flood, since 1970 compared to earlier years (1912-69) (Kolars and others, 2016; Nustad and others, 2016). Depending on how long the wetter conditions may persist, flood risk for the next 25 years (through about 2040), and perhaps longer, may be represented best by scenario A. If a transition to the drier climate state happens in about 25 years, then mean annual flood risk for the next 50 years (that is, through about 2065) may be more indicative of scenario B. However, the curve for scenario B will underestimate flood risk for the earlier years (until the transition happens) and overestimate flood risk for the later years and may not represent the actual flood risk very well in either period. The curve for scenario $\mathrm{C}$ likely will underestimate the true flood risk regardless of when the transition may happen.
Estimated peak flow magnitudes for selected exceedance probabilities and all three future conditions are given in table 7. For condition A (wet equilibrium), which probably best represents flood risk for at least the next 25 years (through about 2040), a 10-percent-per-year chance of regulated streamflow exceeding $6,000 \mathrm{ft}^{3} / \mathrm{s}$ is estimated for the Minot, N. Dak., streamgage, a 1-percent-per-year chance of regulated streamflow exceeding $15,700 \mathrm{ft}^{3} / \mathrm{s}$ is estimated, and a 0.2 -percent-per-year chance of regulated streamflow exceeding $29,300 \mathrm{ft}^{3} / \mathrm{s}$ is estimated. The recorded peak streamflow in 2011 was $26,900 \mathrm{ft}^{3} / \mathrm{s}$, which is similar to the 0.2 -percent-peryear chance estimated peak streamflow magnitude for condition $\mathrm{A}\left(29,300 \mathrm{ft}^{3} / \mathrm{s}\right)$ and nearly twice as large as the 0.2-percent-per-year chance estimated peak streamflow magnitude for condition $\mathrm{C}\left(14,800 \mathrm{ft}^{3} / \mathrm{s}\right)$ (fig. 18; table 7). The estimated 1 -percent annual exceedance probability flood magnitude was $8,800 \mathrm{ft}^{3} / \mathrm{s}$ for condition $\mathrm{C}$ (dry equilibrium).

\section{Summary}

The Souris River Basin is a 24,000-square-mile basin in the Provinces of Saskatchewan and Manitoba in Canada and the State of North Dakota in the United States. Aboveaverage snowpack during the winter of 2010-11, along with record-setting rains in May and June of 2011, led to record flooding that caused extensive damage to Minot, N. Dak., and numerous smaller communities in Saskatchewan, Manitoba, and N. Dak. As a result, the International Souris River Board created the Souris River Flood Task Force to evaluate potential reservoir operation changes and flood control measures to manage future floods and droughts. Part of this evaluation involved identifying a need for a stochastic model to simulate streamflow in the Souris River Basin upstream from Minot,

Table 7. Estimated peak streamflow magnitudes for the Souris River above Minot, North Dakota (U.S. Geological Survey streamgage 05117500), for annual exceedance probabilities of 10, 5, 2, 1, 0.5, and 0.2 percent and three climatic conditions.

[A, (wet equilibrium) representing wet (similar to 1970-2015) climatic conditions; B, (transition) representing transition from wet to dry (similar to 1913-69) climatic conditions; C, (dry equilibrium) representing dry climatic conditions; estimates assume current (1991-2017) reservoir operation]

\begin{tabular}{cccc}
\hline $\begin{array}{c}\text { Annual } \\
\text { exceedance } \\
\text { probability, } \\
\text { in percent }\end{array}$ & $\begin{array}{c}\text { Condition A } \\
\text { (wet equilibrium) }\end{array}$ & $\begin{array}{c}\text { Estimated peak streamflow magnitude, } \\
\text { in cubic feet per second }\end{array}$ \\
\hline 10 & 5,800 to 6,000 & $\begin{array}{c}\text { Condition B } \\
\text { (transition) }\end{array}$ & $\begin{array}{c}\text { Condition C } \\
\text { (dry equilibrium) }\end{array}$ \\
\hline 5 & 7,400 to 8,000 & 4,500 to 4,400 & 3,000 to 2,800 \\
2 & 11,000 to 11,300 & 6,500 to 7,100 & 5,600 to 5,700 \\
1 & 15,600 to 15,700 & 8,700 to 9,100 & 7,500 to 7,800 \\
0.5 & 20,800 to 21,000 & 10,900 to 11,100 & 8,700 to 8,800 \\
0.2 & 29,100 to 29,300 & 15,100 to 15,200 & 10,500 to 10,600 \\
& & 23,500 to 23,000 & 14,700 to 14,800 \\
\hline
\end{tabular}


North Dakota, to estimate the likelihood of future flooding or drought; this need was partly addressed through developing a stochastic model to simulate natural (unregulated) streamflow in the Souris River Basin as described in a previous report.

The stochastic natural streamflow model was built upon through this report to include the effects of regulation from four reservoirs (Rafferty, Alameda, and Boundary Reservoirs and Lake Darling) which are operated according to their operational guidelines. A regulated reservoir storage/streamflow routing model was first developed and calibrated for the period when all four reservoirs were in operation until the end of the reconstructed natural streamflow dataset provided by the U.S. Army Corps of Engineers (1992-2011). Measured and simulated reservoir volumes produced through the regulated reservoir storage/streamflow routing model compared well with correlation coefficients of 0.87 (Rafferty Reservoir), 0.64 (Alameda Reservoir), 0.96 (Boundary Reservoir), and 0.77 (Lake Darling). Additionally, measured and simulated 10-day releases (outflows) from all four reservoirs had similar peaks and low points, as did 10-day mean streamflows at the streamgage Souris River above Minot, N. Dak. The regulated reservoir storage/streamflow routing model then was combined with the previously published stochastic natural streamflow model to provide a stochastic model for simulating regulated streamflow for the upper Souris River Basin.

The stochastic regulated streamflow model can be used to estimate regulated flood frequency curves and provide useful information for feasibility and design of critical structures such as levees or bridges. There was a transition in about 1970 from a period of drier (similar to 1912-69 climatic conditions) to a period of wetter (similar to 1970-2017) climatic conditions in the Souris River Basin. Therefore, three potential future climatic conditions were considered in this analysis: condition A (wet equilibrium), representing wet (similar to 1970-2017) climatic conditions; condition B (transition), representing transition from wet to dry (similar to 1912-69) climatic conditions; and condition $\mathrm{C}$ (dry equilibrium), representing dry climatic conditions. For all three climatic conditions, there were large reductions in the flood frequency curves for regulated flow compared to unregulated, and the largest reduction was for moderate (5-percent to 1-percent) exceedance probabilities. The reductions were less for the extreme (less than 1-percent) exceedance probabilities. A comparison among regulated conditions for the three different climatic conditions indicated the regulated flood frequency curves were highly sensitive to the climatic conditions for the more extreme exceedance probabilities (less than 1 percent). The estimated 1-percent annual exceedance probability flood magnitude for the Souris River upstream from Minot, N. Dak., was 15,700 cubic feet per second $\left(\mathrm{ft}^{3} / \mathrm{s}\right)$ for condition $\mathrm{A}$ (wet equilibrium), compared to $8,800 \mathrm{ft}^{3} / \mathrm{s}$ for condition $\mathrm{C}$ (dry equilibrium). The estimated 0.2-percent annual exceedance probability flood magnitude for the same streamgage was $29,300 \mathrm{ft}^{3} / \mathrm{s}$ for condition A (wet equilibrium), compared to 14,800 for condition $\mathrm{C}$ (dry equilibrium). For comparison, the recorded peak flow for 2011 for the Souris River upstream from Minot, N. Dak., was $26,900 \mathrm{ft}^{3} / \mathrm{s}$.

Although it is not possible to predict how long the current (1970-2017) wet climatic conditions may persist, flood risk for the near future (at least the next 25 years, or until about 2040)) may be represented best by climatic condition A, which represents equilibrium conditions for the wet (similar to 1970-2017) climatic conditions. The curve for climatic condition $\mathrm{B}$, which represents a mixture of wet and dry (similar to 1911-69) climatic conditions, may underestimate flood risk for the next two decades (until the transition back to the drier climatic conditions happens) and overestimate flood risk for the later years and may not represent the actual flood risk very well in either period. The curve for climatic condition C, which represents equilibrium conditions for the dry climatic state, likely will underestimate the true flood risk during the next 25 years and perhaps longer depending on when the transition back to the dry climatic conditions may occur.

\section{References Cited}

Government of Canada, 2014, Adjusted and homogenized Canadian climate data: Government of Canada web page, accessed July 15, 2015, at https://ec.gc.ca/dccha-ahccd/ default.asp?lang $=$ En\&n=B1F8423A-1.

Government of Canada, 2017, Real-time hydrometric data: Government of Canada web page, accessed December 16, 2017, at https://wateroffice.ec.gc.ca/mainmenu/real_time_ data_index_e.html.

Helsel, D.R., and Hirsch, R.M., 2002, Statistical methods in water resources: U.S. Geological Survey Techniques of Water-Resources Investigations, book 4, chap. A3, 522 p.

International Joint Commission, 1989, Boundary watersAgreement between the Government of Canada and the Government of the United States of America for water supply and flood control in the Souris River Basin (with annexes and Canada/Saskatchewan agreement): Ottawa, Queen's Printer for Canada, $36 \mathrm{p}$.

International Souris River Board, 2013, Plan of study-For the review of the operating plan contained in Annex A of the 1989 international agreement between the Government of Canada and the Government of the United States: Souris River Basin Task Force Report, 197 p.

Kolars, K.A., Vecchia, A.V., and Ryberg, K.R., 2016, Stochastic model for simulating Souris River Basin precipitation, evapotranspiration, and natural streamflow: U.S. Geological Survey Scientific Investigations Report 2015-5185, 55 p. [Also available at https://doi.org/10.3133/sir20155185.] 
Lake Darling Water Control Manual, 2012, Lake Darling dam and reservoir Souris River Basin flood control: U.S. Army Corps of Engineers, St. Paul District, November 2012.

Menne, M.J., Williams, C.N., Jr., and Vose, R.S., 2014, United States Historical Climatology Network (USHCN) version 2.5 serial monthly dataset: National Climatic Data Center, National Oceanic and Atmospheric Administration, accessed May 15, 2014, at http://cdiac.ornl.gov/ftp/ushcn_ v2.5 monthly/.

National Oceanic and Atmospheric Administration, National Climatic Data Center, 2014, Tree ring: National Oceanic and Atmospheric Administration web page, accessed July 15, 2014, at https:/www.ncdc.noaa.gov/data-access/paleoclimatology-data/datasets/tree-ring.

Nustad, R.A., Kolars, K.A., Vecchia, A.V., and Ryberg, K.R., 2016, 2011 Souris River flood-Will it happen again?: U.S. Geological Survey Fact Sheet 2016-3073, 4 p. [Also available at https://doi.org/10.3133/fs20163073.]

R Core Team, 2015, R-A language and environment for statistical computing: Vienna, Austria, R Foundation for Statistical Computing, accessed September 30, 2015, at http://www.R-project.org.
Ryberg, K.R., Vecchia, A.V., Akyuz, A., and Lin, W., 2016, Tree-ring-based estimates of long-term seasonal precipitation in the Souris River Region of Saskatchewan, North Dakota and Manitoba: Canadian Water Resources Journal, v. 41, no. 3, p. 412-428.

U.S. Army Corps of Engineers, 2013, Regional reconstructed hydrology of the Souris River: U.S. Army Corps of Engineers, St. Paul District, 158 p.

U.S. Geological Survey, 2017, USGS water data for the Nation: U.S. Geological Survey National Water Information System database, accessed December 16, 2017, at https:// doi.org/10.5066/F7P55KJN.

Vecchia, A.V., 2011, Simulation of the effects of Devils Lake outlet alternatives on future lake levels and water quality in the Sheyenne River and Red River of the North: U.S. Geological Survey Scientific Investigations Report 2011-5050, 60 p. [Also available at https://pubs.er.usgs.gov/publication/ sir20115050.]

Vining, K.C., Chase, K.J., and Loss, G.R., 2013, General weather conditions and precipitation contributing to the 2011 flooding in the Mississippi River and Red River of the North Basins, December 2010 through July 2011: U.S. Geological Survey Professional Paper 1798-B, 22 p. [Also available at https://pubs.usgs.gov/pp/1798b/.]
For more information about this publication, contact:

Director, USGS Dakota Water Science Center

821 East Interstate Avenue

Bismarck, ND 58503

701-250-7400

For additional information, visit: https://www.usgs.gov/centers/dakotawater

Publishing support provided by the

Rolla Publishing Service Center 



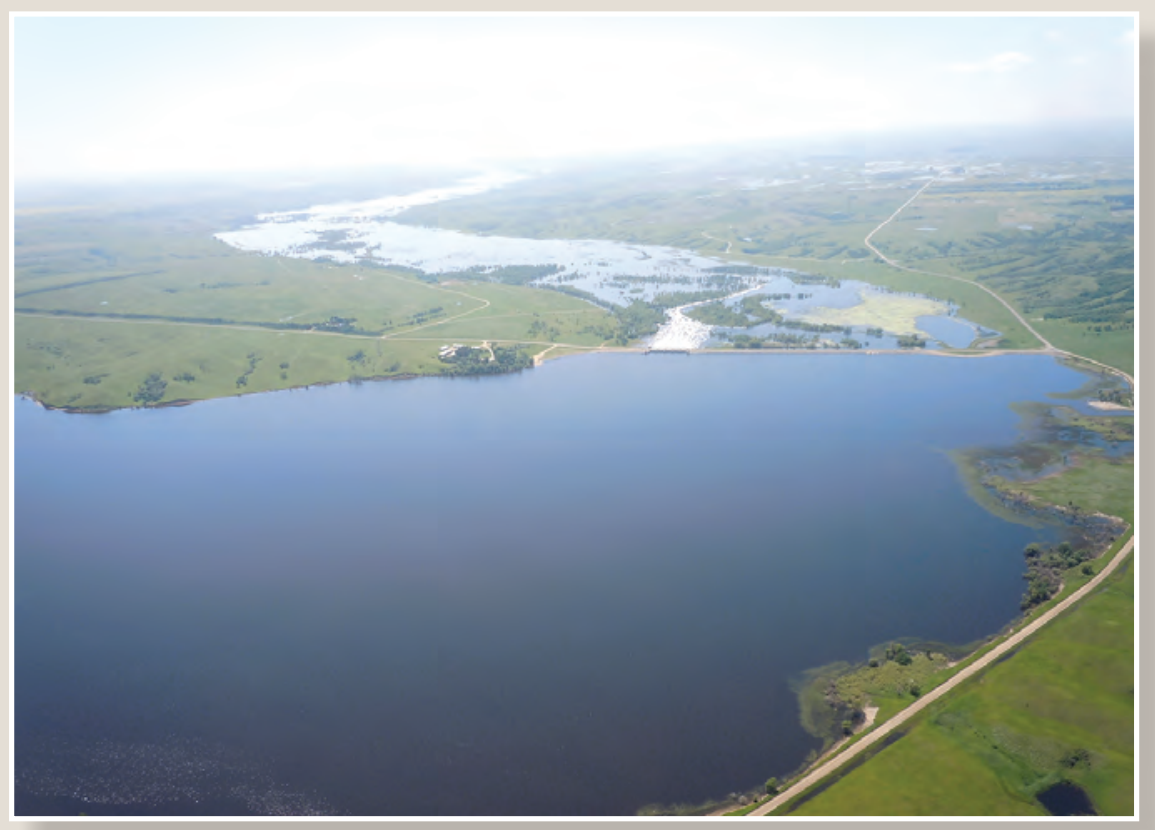

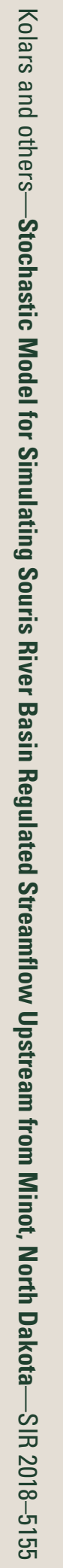

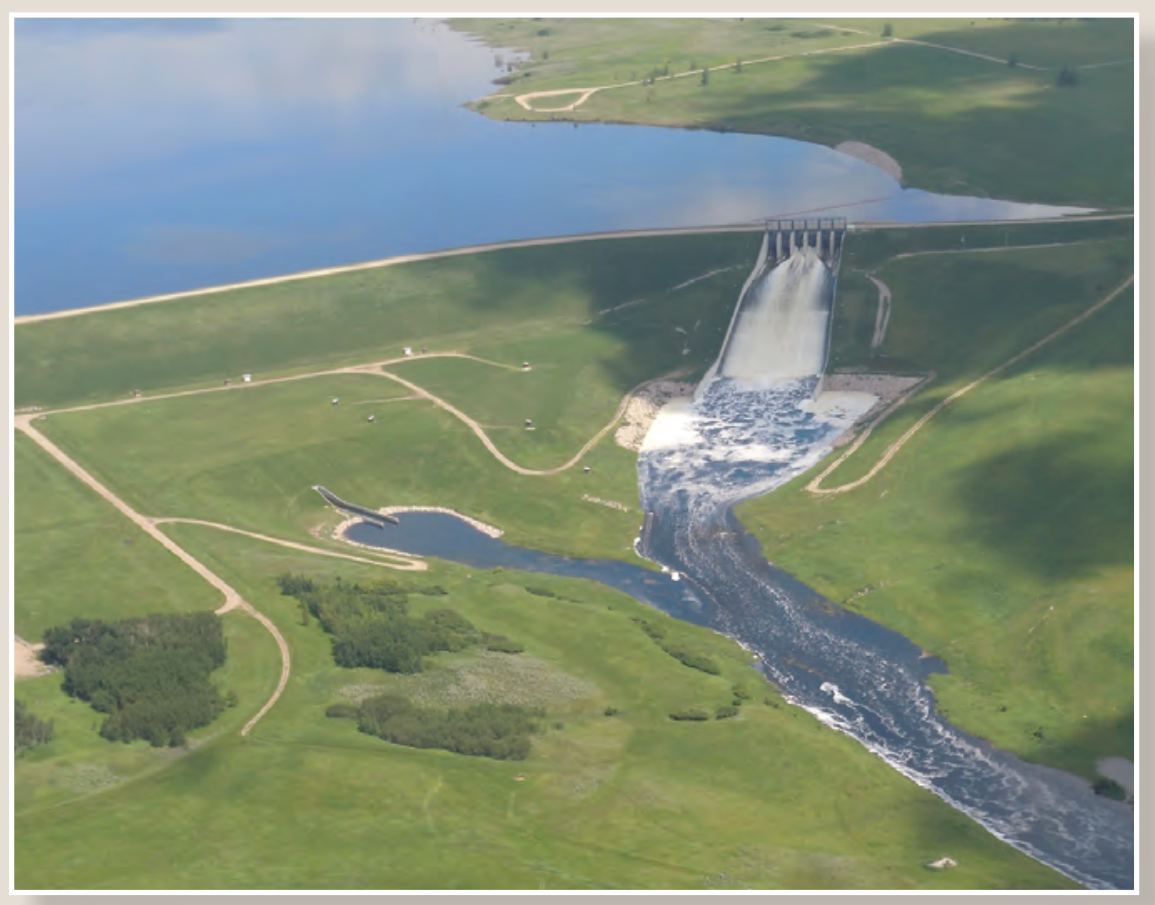

